\title{
33. PETROLOGY AND GEOCHEMISTRY OF BASALTIC ROCKS RECOVERED ON LEG 43 OF THE DEEP SEA DRILLING PROJECT
}

Robert L. Houghton, Department of Earth and Planetary Sciences, Massachusetts Institute of Technology, Cambridge, Massachusetts and Department of Geology and Geophysics, Woods Hole Oceanographic Institution,

Woods Hole, Massachusetts

\begin{abstract}
All basaltic rocks recovered on Leg 43 are moderately to intensely altered. Immobile element relationships are used to characterize the magmatic types encountered. Basaltic clasts from the volcaniclastic breccias of Nashville (Site 382) and Vogel (Site 385) seamounts display both petrographic and geochemical variability. Four highly alkalic basalt types and one possible LIL-element enriched tholeiite are defined within the suite sampled. A Miocene basaltic sill in Upper Cretaceous clays on the flank of Vogel resembles another Miocene sill encountered at DSDP Site 10,880 km away. Temporal and spatial relations suggest renewed activity may have occurred along the New England Seamount chain at this time.

Basalts recovered at Site 384 from $J$-anomaly. Ridge are chemically modified by both high- and low-temperature alteration. They are chemically akin to normal ocean ridge tholeiites, however, and offer no explanation for the $J$-anomaly.

Site 386 in the central Bermuda Rise yielded moderately altered basalt similar to that found on mid-ocean ridges. It is petrographically similar to rocks recovered at DSDP Site 100. Basalt from Site 387 in the western Bermuda Rise is petrographically and structurally interpreted as a sill. The chemistry of this basalt is variable. One sample displays moderate LIL-element enrichments as in oceanic island tholeiites, supporting a sill origin; another sample resembles ridge tholeiite, suggesting the basalt may instead represent two flows.
\end{abstract}

\section{INTRODUCTION}

Basalt was recovered during Leg 43 of the Deep Sea Drilling Project (DSDP) at five sites in the North Atlantic Ocean (Figure 1). Two sites are on seamounts and three at ocean crust locales. Details of drilling and geologic summaries are given elsewhere in this volume (Chapters 2 through 7). Sample locations and the numbering system used in this report are shown in Figure 2.

Petrographic and geochemical studies were planned with four principal objectives in mind: (1) determination of the nature and petrogenesis of the original magmas; (2) comparison of the Leg 43 basalts of different ages with each other and with other basalts recovered in the western North Atlantic (DSDP Sites $10,11,100$, and 105) and from the Mid-Atlantic Ridge axis; (3) determination of magmatic variations along a linear seamount chain (the New England seamount chain), and (4) determination of the extent of geochemical and mineralogical changes caused by alteration processes. As all material recovered is moderately to intensely altered, magmatic characterizations are largely contingent on the relationships of the refractory (immobile) elements (Pearce and Cann, 1973; Bass et al., 1973; Floyd and Winchester, 1975).

\section{ANALYTICAL TECHNIQUES}

Basalt samples from Sites 382 and 385 were obtained as quarter-core pieces from clasts within the volcaniclastic breccia units of the holes. An additional sample was obtained at Site 385 from a sill at 283 meters sub-bottom depth. Samples from Sites 384, 386, and 387 consisted of $2-\mathrm{cm}$-long pieces of $2.2-\mathrm{cm}$ diameter transverse cores (drilled at right angles to the DSDP core) within the respective basalt units.

Doubly polished, uncovered thin sections were made of selected portions of all samples collected. Extensive petrographic examination using transmitted and reflected light microscopy was employed to identify mineralogy and select the least-altered material for chemical analysis. Groundmass mineralogy was verified by X-ray diffraction.

Representative phenocryst phases were analyzed using the PDP 11 computer-automated electron microprobe at M.I.T. At least 10 replicate analyses per phenocryst were used to check precision. Accuracy, checked by comparison of results for a plagioclase 


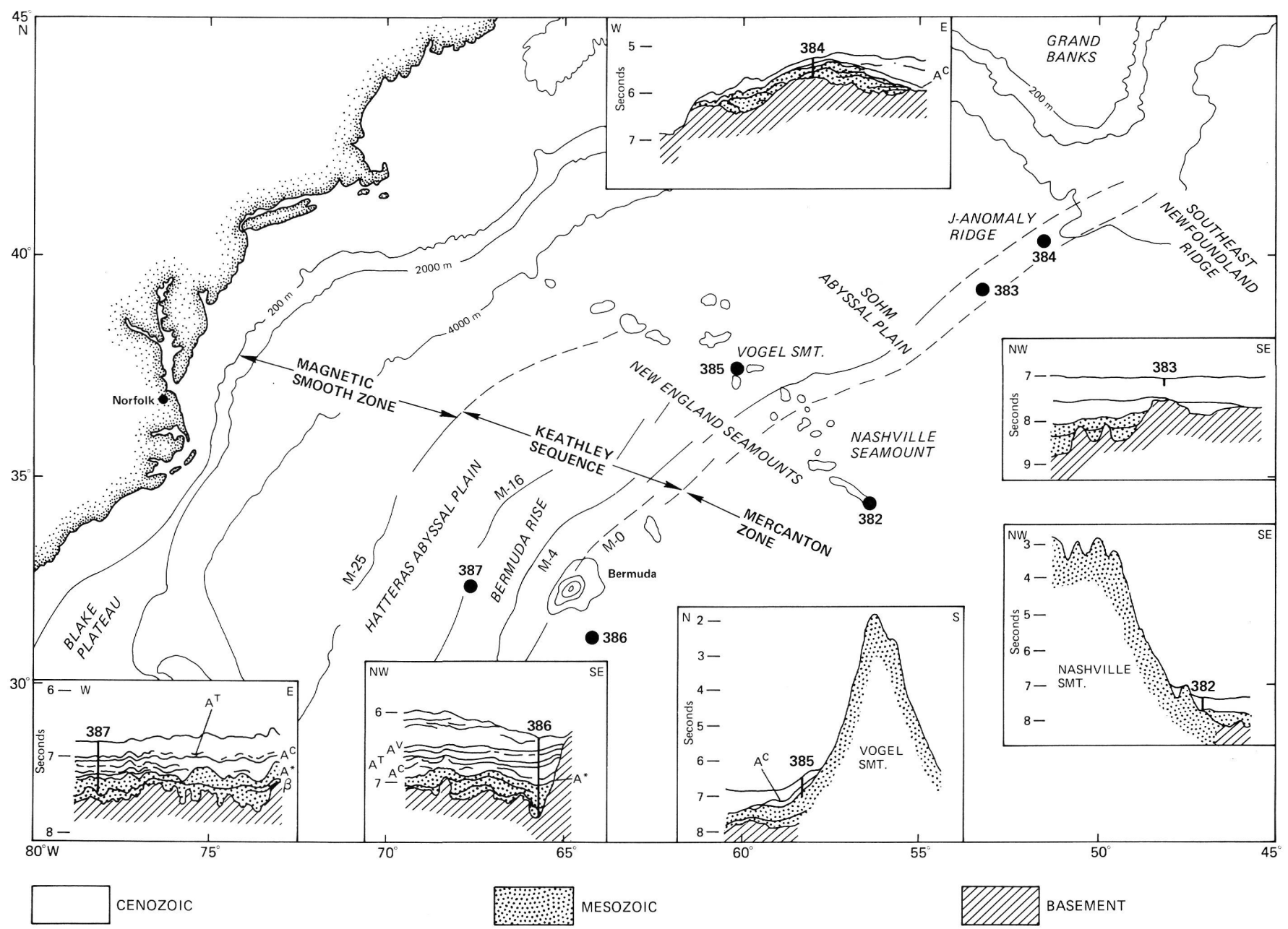

Figure 1. Location of DSDP sites drilled on Leg 43.

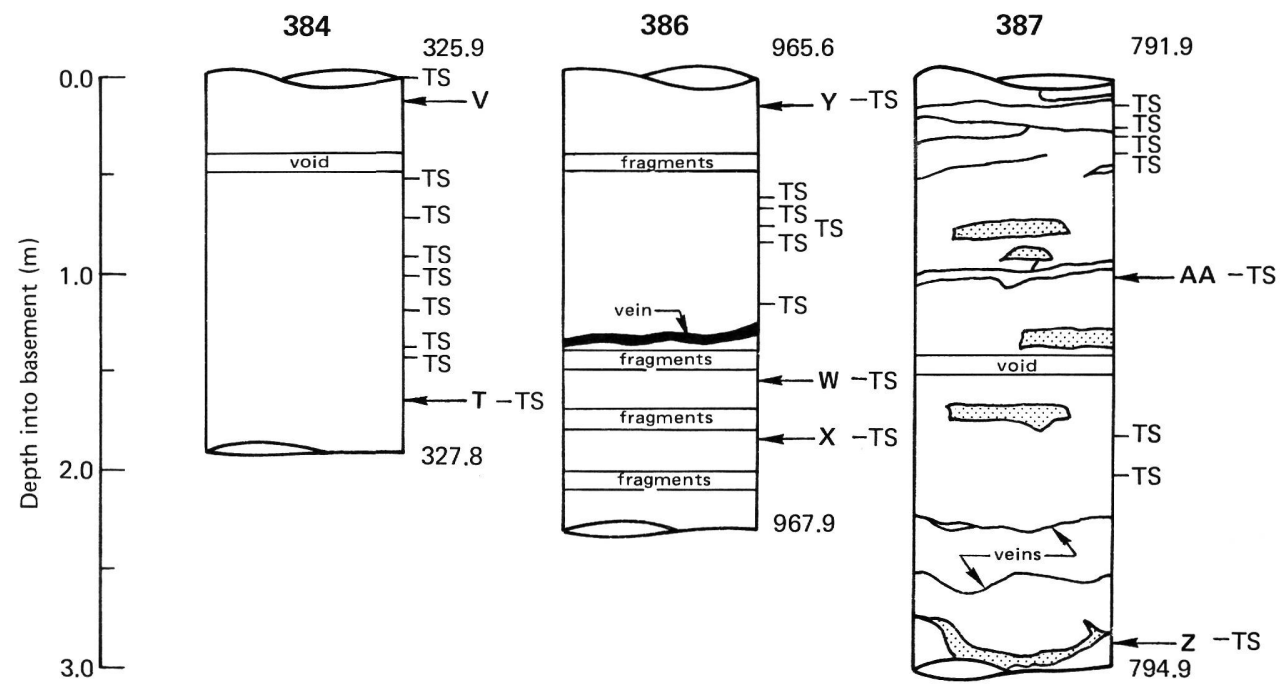

Figure 2. Leg 43 basalt units with sample distribution and numbering as used in this paper. TS means thin section. 
TABLE 1

Analyses of Standard Rocks

\begin{tabular}{lccccccccc}
\hline & \multicolumn{2}{c}{ Major Elements } & \multicolumn{3}{c}{ Trace Elements } & \multicolumn{3}{c}{ Trace Elements } \\
& $(1)^{\mathrm{a}}$ & $(2)^{\mathrm{b}}$ & & $(3)^{\mathrm{c}}$ & $(4)^{\mathrm{d}}$ & & $(5)^{\mathrm{e}}$ & $(6)^{\mathrm{f}}$ \\
\hline $\mathrm{SiO}_{2}$ & 54.50 & $54.91 \pm 0.2$ & $\mathrm{~V}$ & 399 & 361 & \pm 3 & $\mathrm{La}$ & 26 & 27.8 \\
$\mathrm{Al}_{2} \mathrm{O}_{3}$ & 13.61 & $13.18 \pm 0.2$ & $\mathrm{Cr}$ & 17.6 & $17.1 \pm 0.8$ & $\mathrm{Ce}$ & 53.9 & 51.7 \\
$\mathrm{FeO}$ & 12.11 & $12.08 \pm 0.1$ & $\mathrm{Co}$ & 38 & 40 & \pm 2 & $\mathrm{Nd}$ & 29 & 27.8 \\
$\mathrm{MgO}$ & 3.46 & $3.69 \pm 0.2$ & $\mathrm{Ni}$ & 15.8 & 16 & \pm 1 & $\mathrm{Sm}$ & 6.6 & 6.61 \\
$\mathrm{CaO}$ & 6.92 & $6.80 \pm 0.1$ & $\mathrm{Cu}$ & 18.4 & 18 & \pm 1 & $\mathrm{Eu}$ & 1.94 & 1.89 \\
$\mathrm{Na} 2 \mathrm{O}$ & 3.27 & $3.57 \pm 0.17$ & $\mathrm{Zn}$ & 120 & 112 & \pm 2 & $\mathrm{~Tb}$ & 1.0 & 1.15 \\
$\mathrm{~K}_{2} \mathrm{O}$ & 1.70 & $1.67 \pm 0.01$ & $\mathrm{Ga}$ & 20 & 22 & \pm 1 & $\mathrm{Ho}$ & 1.2 & 1.28 \\
$\mathrm{TiO}_{2}$ & 2.20 & $2.21 \pm 0.04$ & $\mathrm{Sr}$ & 330 & 300 & \pm 7 & $\mathrm{Yb}$ & 3.36 & 3.41 \\
$\mathrm{MnO}$ & 0.18 & $0.18 \pm 0.02$ & $\mathrm{Ba}$ & 675 & 655 & \pm 7 & $\mathrm{Lu}$ & 0.55 & 0.561 \\
$\mathrm{P}_{2} \mathrm{O}_{5}$ & 0.36 & $0.34 \pm 0.03$ & $\mathrm{Y}$ & 37.1 & 37 & \pm 1 & $\mathrm{Hf}$ & 4.7 & 5.22 \\
$\mathrm{H}_{2} \mathrm{O}^{+}$ & 0.77 & $0.83 \pm 0.05$ & $\mathrm{Zr}$ & 190 & 182 & \pm 6 & $\mathrm{Ta}$ & 0.91 & 0.837 \\
$\mathrm{H}_{2} \mathrm{O}^{-}$ & 0.80 & $0.76 \pm 0.04$ & & & & & $\mathrm{Sc}$ & 33 & 32.1 \\
$\mathrm{CO}_{2}$ & 0.03 & $0.01 \pm 0.01$ & & & & & & & \\
$\mathrm{Total}$ & 100.28 & 100.23 & & & & & & & \\
\hline
\end{tabular}

\footnotetext{
${ }_{b}^{\mathrm{a}}$ Recommended values for BCR-1 (Flanagan, 1973).

${ }^{\mathrm{b}}$ Mean and standard deviation of electron microprobe (MIT) analyses of 5 different chips of prepared unfluxed BCR-1 glass.

Recommended trace element values for BCR-1 (Flanagan, 1973).

$\mathrm{d}$ Mean and standard deviation of X-ray fluorescence data obtained for BCR-1 during analysis of Leg 43 samples.

Recommended values for BCR-1 (Flanagan, 1973).

$\mathrm{f}$ Instrumental neutron activation analysis of BCR-1.
}

phenocryst with wet chemical analyses supplied by W. G. Melson, was good to excellent. $\mathrm{H}_{2} \mathrm{O}$ was determined as weight loss at $650^{\circ} \mathrm{C}$.

Selected whole-rock samples were crushed in an agate mortar to pass 200 mesh. Major elements were determined on unfluxed glasses prepared from $1-\mathrm{g}$ splits of this rock powder using the electron microprobe. These splits were first ignited at $1000^{\circ} \mathrm{C}$ for two to three hours to decompose hydrous and carbonate phases and oxidize all iron to the ferric state. After weighing to determine ignition loss, about $0.75 \mathrm{~g}$ of powder was loaded into a platinum capsule and compacted by centrifuging. The open end of the capsule was crimped and welded shut to make the capsule airtight. Fusion was obtained by suspending the capsules individually in a platinum-wound furnace at $1350^{\circ} \mathrm{C}$ for 40 minutes. Quenching in water produced dark brown, homogeneous glasses from the basaltic powders. Although platinum is notorious for adsorbing iron, iron must be reduced to its metallic state before adsorption can occur; frazzling the powder before loading the capsules encourages oxidizing conditions in the sealed capsule. Microprobe analysis of the capsule walls detected no iron loss to the platinum. At least 10 analyses per glass were averaged. Accuracy of analysis of BCR-1 proved excellent by this method, save a tendency for the M.I.T. probe to yield systematically high values for $\mathrm{MgO}$ and $\mathrm{Na}_{2} \mathrm{O}$ (Table 1) as earlier reported by Frey et al., (1974). This error has since been traced to a standard problem and corrected.

Ferrous iron was determined by the Wilson technique as modified by Maxwell (1968). Total $\mathrm{H}_{2} \mathrm{O}$ and $\mathrm{CO}_{2}$ determinations were performed by gas chromatography.

Minor elements $\mathrm{Ba}, \mathrm{Co}, \mathrm{Cu}, \mathrm{Cr}, \mathrm{Ga}, \mathrm{Pb}, \mathrm{Ni}, \mathrm{Sr}, \mathrm{V}$, $\mathrm{Y}, \mathrm{Zn}$, and $\mathrm{Zr}$ were analyzed on powder splits by
$\mathrm{X}$-ray fluorescence. Three grams of each sample were pelletized under vacuum in an evacuable die at 30 tons pressure and dried overnight at $110^{\circ} \mathrm{C}$ to remove adsorbed water. Matrix corrections were made using Reynolds' (1963) method. Reynolds' (1967) method was employed for Co. Four international rock standards, USGS G-2, USGS W-1, USGS BCR-1, and CCRM MRG-1, were used to generate the calibration curve because their major and trace element compositions are relatively well known and range around those of oceanic basalts. Duplicate analyses of selected samples on opposite sides of the pellet gave small differences in line intensity ( $<1 \%$ to $3 \%$, increasing with increasing wavelength). Average relative counting error was calculated for each element and was in all cases significantly smaller than the standard deviation of the calibration line.

Neutron activation analysis (Gordon et al., 1968) was used to measure $\mathrm{La}, \mathrm{Ce}, \mathrm{Nd}, \mathrm{Sm}, \mathrm{Eu}, \mathrm{Tb}, \mathrm{Ho}, \mathrm{Yb}$, $\mathrm{Lu}, \mathrm{Sc}, \mathrm{Hf}$, and $\mathrm{Ta}$ concentrations. For large ion lithophile (LIL) element enriched basalts, the precision of this procedure is believed to be \pm 5 - 15 per cent (Frey et al., 1974).

\section{PETROGRAPHY}

\section{Site 382, Flank of Nashville Seamount}

Two crystal-lithic lapilli tuffs cored at 385.6-404.0 meters and 473.3-520.5 meters below the sea floor yield a variety of volcanic material. Angular to subangular basaltic clasts in various stages of alteration from minor greenschist metamorphism to complete oxidation, and relatively fresh laths of hornblende and pyroxene, are cemented by calcite and phillipsite with lesser chalcedony and epidote (Figure 3). Textural variations within the breccia are detailed in Chapter 2, 


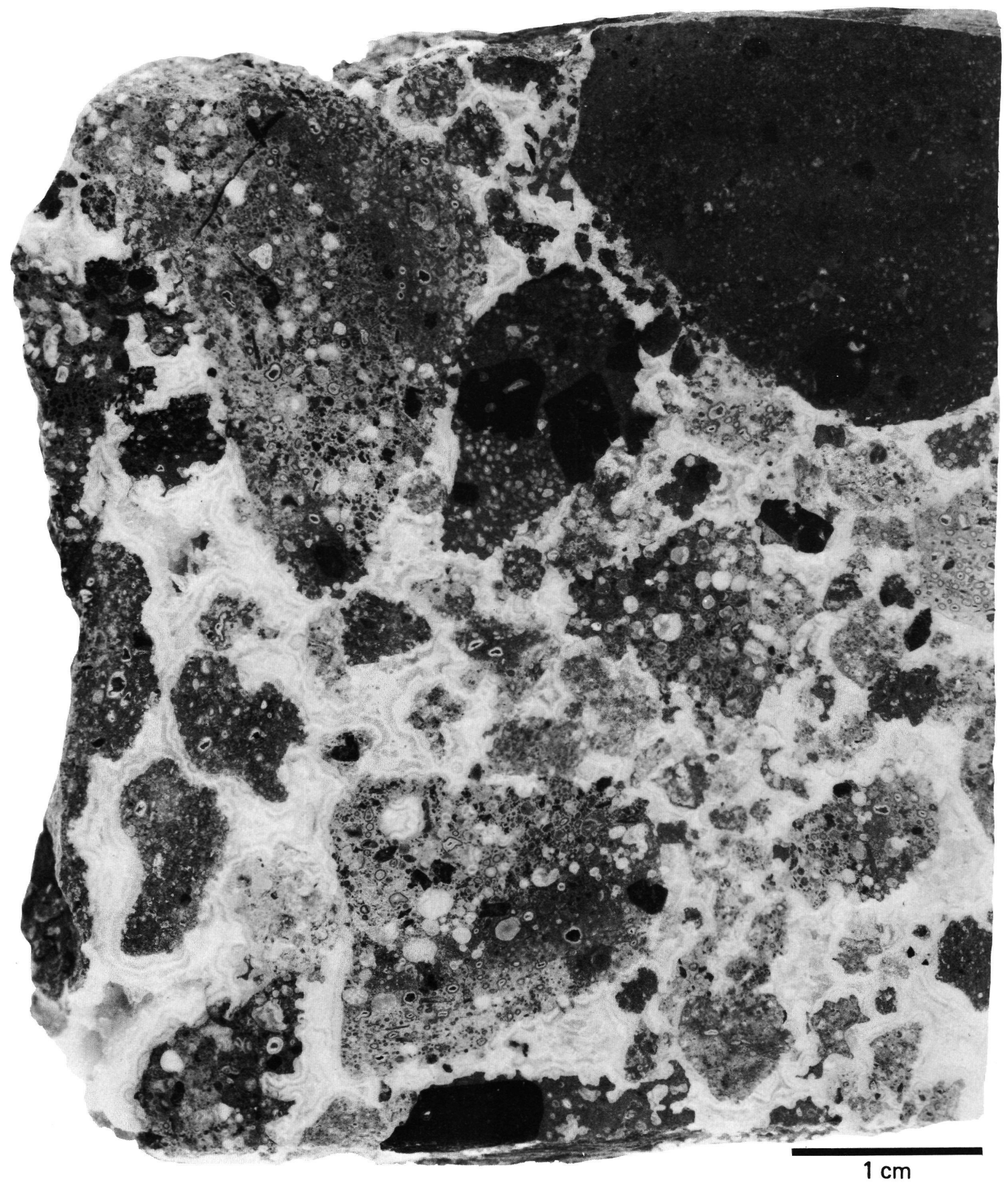

Figure 3. Typical cementation of volcaniclastic breccias of Sites 382 and 385. 
this volume. The similarity of these volcaniclastic breccias to the Wairakau breccias of New Zealand (Parsons, 1968, 1969) suggests that they could have formed either from subaerial or submarine vulcanian or phreatic eruptions with subsequent deposition in underwater mass flows or turbidity slides.

The wide range of alteration displayed by clasts suggests greatly varying exposure to seawater weathering effects. This variability and the occurrence of two defined breccia units suggest that the clasts represent two or more episodes of eruption. Petrographic diversity supports this conclusion.

Although most basalt clasts are as highly altered as those earlier dredged from Gilliss Seamount by Taylor and Hekinian (1971), a few relatively fresh volcanic rocks make a generalized magmatic characterization possible. Petrographic study suggests the occurrence of five types of basalt based on phenocryst phases: (1) clinopyroxene and olivine; (2) clinopyroxene plus amphibole; (3) plagioclase, clinopyroxene, and amphibole; (4) aphanitic; and (5) olivine plus plagioclase. No pattern of distribution is recognizable within or among the breccia units, so it is impossible to petrologically discriminate between the two observed explosive episodes. As not all breccia clasts were studied, other basalt types may also exist within the unit.

The first basalt type is represented by purplish brown subhedral to euhedral clinopyroxene crystals $(0.5-2.3 \mathrm{~mm})$ and partially resorbed or altered, greenish yellow to greenish gray, olivine $\left(\mathrm{Fo}_{78}\right)$ phenocrysts $(0.5-1.1 \mathrm{~mm})$ in a matrix of randomly oriented plagioclase microlites and interstitial augite. The bright violet-purple pleochroism of the clinopyroxene is characteristic of titanaugite, indicative of an alkalic composition for the basalt. The groundmass tends to be highly weathered to a reddish brown smear of limonite and mixed-layer illite-montmorillonite as confirmed by $\mathrm{X}$-ray diffraction. Ghost plagioclase microlites replaced by a clay mineral (montmorillonite?) are penetrated by thin white needles of phillipsite. Alteration of olivine to iddingsite appears to be most intense in the presence of skeletal magnetite. Anhedral maghemite may also be present ( $<5$ per cent) associated with platy hematite. Although Taylor and Hekinian (1971) reported biotite from similar basalt, none was observed in these specimens. Vesicularity ranges from 6 to 12 per cent, but nearly all vesicles are now completely filled with calcite and alteration products. Electron microprobe analyses of the phenocryst phases are reported in Table 2.

Basalts bearing clinopyroxene and amphibole phenocrysts (type 2) tend to be less altered than other types. Purplish brown and greenish blue titanaugite $(0.5-2 \mathrm{~mm})$ and brown to brown-green hornblende $(0.9-8 \mathrm{~mm})$ phenocrysts occur in a pilotaxitic or subtrachytic groundmass of plagioclase with minor clinopyroxene. Minor alteration of the subhedral to euhedral phenocrysts is indicated by increased birefringence and absorption. The phyric hornblende is commonly zoned on the [110] face. Zoning, the extreme size of some hornblende crystals (up to $2.5 \mathrm{~cm}$ ), and the lack of intermediary alteration products preclude a secondary origin for this amphibole. Groundmass limonite and mixed-layer illite-montmorillonite are the most common alteration products. Anhedral magnetite $(<7 \%)$ is disseminated throughout. In general, pseudo-vesicles filled with white spherulitic aggregates occupy $<5$ per cent of the sample. These spheres of radiating needles of clinoptilolite bear cores of badly corroded hightemperature sanidine. The latter are interpreted as phenocrysts being altered to zeolite in this highly alkaline lava. This occurrence is discussed more extensively by Houghton, Rothe, and Galehouse (this volume).

The most abundant basalt type sampled (type 3 ) is characterized by plagioclase, clinopyroxene, and amphibole phenocrysts. Coarsest of the materials sampled, these basalts have an ophitic matrix locally modified by feather plagioclase $\left(\mathrm{An}_{68-75}\right)$ crystals similar to those illustrated from Site 105 (Bryan, 1972). Textures approach those of cumulate gabbros, and vesicularity is low. Infrequent rod magnetite is dispersed throughout. Plagioclase phenocrysts are subhedral and glomerophyric zoned labradorite $\left(A n_{72-75}\right)$, some of which enmesh clinopyroxene phenocrysts. Titanaugites $(0.5-4$ $\mathrm{mm}$ ) are clear and euhedral, not patchy as expected for crystals being affected by alteration. Amphibole phenocrysts $(1-15 \mathrm{~mm})$ include common hornblende and rare kaersutite. While the former are characteristically concordantly zoned, the kaersutite is a patchy violet, invariably partially bordered by magnetite. Partial alteration of titanaugite to kaersutite (Aoki, 1963 ) is suggested.

Type 4 basalt is entirely devoid of phenocrysts. Alteration is very intense, with most specimens consisting of a reddish brown aggregation of amorphous limonite, illite, montmorillonite, and magnetite. Original textures are usually variolitic. Abundant vesicles $(>12 \%)$ average $0.7 \mathrm{~mm}$ in diameter and contain assemblages of chlorite, calcite, and phillipsite.

A single type 5 basalt sample, characterized by extensive iddingsite replacement of phyric olivine $\left(\mathrm{Fo}_{83}\right)$ and minor plagioclase $\left(\mathrm{An}_{65-66}\right)$ phenocrysts mostly replaced by montmorillonite, was recovered from the lower breccia unit at a sub-bottom depth of 518.3 meters. The groundmass is pilotaxitic in texture, comprised of small laths of plagioclase $\left(A n_{52-55}\right)$ and small grains of pyroxene, both of which are highly altered to illite-montmorillonite mixed-layer clays, speckled with small subhedral rutile. The diopsidic nature of the least-altered pyroxene suggests this one basalt may be tholeiitic. This basalt usually has a high vesicularity $(>7 \%)$, with vesicle rims sometimes bordered with brownish red palagonite. Most vesicles are filled with milky white, fibrous phillipsite and montmorillonite, probably formed from the weathering of groundmass plagioclase.

\section{Site 385, Flank of Vogel Seamount}

Fifty-five meters of nearly continuous volcaniclastic breccia were penetrated. Textural and compositional details suggest an origin similar to that which formed the breccias at Site 382 (see Chapter 5, this volume).

The petrography of the basaltic clasts is identical to that of types 3 and 4 at Site 382. Although no glass 
TABLE 2

Mineral Compositions Determined by Electron Microprobe

\begin{tabular}{|c|c|c|c|c|c|c|c|c|c|}
\hline & (1) & (2) & (3) & (4) & (5) & (6) & (7) & (8) & (9) \\
\hline $\mathrm{SiO}_{2}$ & 49.39 & 32.16 & 49.00 & 44.21 & 41.46 & 47.98 & 40.01 & 52.81 & 39.3 \\
\hline $\mathrm{Al}_{2} \mathrm{O}_{3}$ & 2.48 & 0.84 & 1.28 & 8.58 & 11.68 & 2.80 & 12.08 & 29.71 & 0.76 \\
\hline $\mathrm{FeO} *$ & 11.00 & 39.53 & 11.12 & 7.32 & 8.80 & 6.35 & 12.72 & 0.78 & 9.92 \\
\hline $\mathrm{MgO}$ & 12.96 & 24.31 & 13.64 & 12.01 & 10.35 & 16.43 & 11.23 & 0.02 & 48.43 \\
\hline $\mathrm{CaO}$ & 12.20 & 0.68 & 12.88 & 23.23 & 21.58 & 19.99 & 11.05 & 12.01 & 0.46 \\
\hline $\mathrm{Na}_{2} \mathrm{O}$ & 2.44 & 0.00 & 3.66 & 0.47 & 0.75 & 0.41 & 3.28 & 4.24 & 0.02 \\
\hline $\mathrm{K}_{2} \mathrm{O}$ & 2.25 & 0.01 & 3.13 & 0.00 & 0.08 & 0.08 & 1.17 & 0.19 & 0.04 \\
\hline $\mathrm{TiO}_{2}$ & 5.96 & 0.71 & 3.24 & 3.63 & 5.61 & 5.42 & 7.21 & 0.03 & 0.58 \\
\hline $\mathrm{MnO}$ & 0.14 & 0.81 & 0.91 & 0.10 & 0.15 & 0.17 & 0.16 & 0.01 & 0.20 \\
\hline $\mathrm{Cr}_{2} \mathrm{O}_{3}$ & n.d. & n.d. & n.d. & n.d. & n.d. & n.d. & n.d. & n.d. & n.d. \\
\hline $\mathrm{H}_{2} \mathrm{O}$ & 1.03 & 0.31 & 0.42 & 0.47 & 0.11 & 0.10 & 0.59 & 0.05 & 0.26 \\
\hline \multirow[t]{2}{*}{ Total } & 99.86 & 99.36 & 99.28 & 100.03 & 100.59 & 99.73 & 99.50 & 99.80 & 99.97 \\
\hline & (10) & (11) & (12) & (13) & (14) & (15) & (16) & (17) & (18) \\
\hline $\mathrm{SiO}_{2}$ & 54.09 & 41.56 & 48.02 & 49.5 & 50.6 & 51.7 & 52.1 & 49.9 & 51.3 \\
\hline $\mathrm{Al}_{2} \mathrm{O}_{3}$ & 1.57 & 11.39 & 2.97 & 5.16 & 30.7 & 30.1 & 3.11 & 30.5 & 3.95 \\
\hline $\mathrm{FeO} *$ & 3.96 & 8.83 & 6.44 & 8.80 & 0.67 & 0.58 & 8.91 & 0.69 & 10.27 \\
\hline $\mathrm{MgO}$ & 18.89 & 10.31 & 16.51 & 13.6 & 0.48 & 0.23 & 21.91 & 0.51 & 21.00 \\
\hline $\mathrm{CaO}$ & 18.84 & 21.11 & 19.65 & 20.5 & 15.4 & 13.7 & 11.80 & 16.7 & 10.48 \\
\hline $\mathrm{Na}_{2} \mathrm{O}$ & 1.37 & 0.81 & 0.39 & 0.34 & 3.51 & 3.43 & 0.24 & 2.67 & 0.33 \\
\hline $\mathrm{K}_{2} \mathrm{O}$ & 0.15 & 0.07 & 0.10 & n.d. & 0.07 & 0.00 & 0.00 & 0.00 & 0.00 \\
\hline $\mathrm{TiO}_{2}$ & 0.28 & 5.22 & 5.40 & 1.99 & 0.06 & 0.07 & 0.86 & 0.02 & 0.60 \\
\hline $\mathrm{MnO}$ & 0.09 & 0.18 & 0.15 & 0.11 & n.d. & n.d. & 0.21 & n.d. & 0.18 \\
\hline $\mathrm{Cr}_{2} \mathrm{O}_{3}$ & 1.10 & n.d. & n.d. & 0.05 & n.d. & n.d. & 0.44 & n.d. & 1.09 \\
\hline $\mathrm{H}_{2} \mathrm{O}$ & 0.30 & 0.33 & 0.13 & n.d. & n.d. & n.d. & n.d. & n.d. & n.d. \\
\hline Total & 100.64 & 99.81 & 99.76 & 100.05 & 101.49 & 99.81 & 99.58 & 100.99 & 99.20 \\
\hline
\end{tabular}

Note: $\mathrm{FeO}^{*}$ is total iron as $\mathrm{FeO}$; n.d. means not determined. (1) Mean of 12 phenocrysts of augite partially altered to an amphibole (note high $\mathrm{H}_{2} \mathrm{O}$ and $\mathrm{K}_{2} \mathrm{O}$ ) from type 1 basalt, 38224-2, 67-69 cm; (2) Mean of 12 phenocrysts of olivine from type 1 basalt, 382-24-2, 67-69 cm; (3) Mean of 10 augite phenocrysts partially altered to amphibole from type 2 basalt, 382-24-2, $124-128 \mathrm{~cm}$; (4) Mean of 12 hornblende phenocrysts from type 2 basalt, 382-24-2, 124-128 cm; (5) Mean of 12 hornblende phenocrysts from type 3 basalt, 382-25-2, 105-108 cm; (6) Mean of 8 titanaugite phenocrysts from type 3 basalt, 382-25-2, 105-108 cm; (7) Mean of 5 kaersutite phenocrysts from type 3 basalt, 382-25-2, 105-108 cm; (8) Mean of 12 plagioclase phenocrysts from type 3 basalt, 382-25-2, 105-108 cm; (9) Mean of 4 olivine phenocrysts from type 5 basalt, 382-25-2, 125-130 cm; (10) Mean of 6 pyroxene phenocrysts from type 5 basalt, 38225-2, 125-130 cm; (11) Mean of 15 hornblende phenocrysts from type 3 basalt, 385-20, CC $(11-15 \mathrm{~cm})$; (12) Mean of 8 titanaugite phenocrysts from type 3 basalt, 385-20, CC $(11-15 \mathrm{~cm})$; (13) Mean of 10 pyroxene phenocrysts from basalt 384-22, CC (146-148 cm); (14) Mean of 10 plagioclase phenocrysts from basalt $384-22$, CC $(146-148 \mathrm{~cm}) ;(15)$ Mean of 10 plagioclase phenocrysts from basalt 386-66, CC $(13-15 \mathrm{~cm})$; (16) Mean of 8 pyroxene phenocrysts from basalt 386-66, CC (13-15 cm); (17) Mean of 6 plagioclase phenocrysts from basalt 387-50-2, $134-137 \mathrm{~cm}$; (18) Mean of 5 pyroxene phenocrysts from basalt 387-50-2, 134-137 cm.

was found at either site, "fossil"' unfilled shard-shaped cavities were observed in otherwise completely zeolitized regions of the Vogel tuff unit. High sanidineclinoptilolite spherules are also more abundant in the highly altered basalt clasts of Vogel than in the Nashville section.

At 283 meters sub-bottom depth, two grayish brown basaltic fragments with lineations of unfilled vesicles were recovered within Upper Cretaceous clays. The basalt is holocrystalline, microcrystalline aphanitic with a felted pilotaxitic texture. Strongly zoned plagioclase $\left(\mathrm{An}_{50-60}\right)$ microlites $(<2 \mathrm{~mm})$ surround small subangular grains of titaniferous augite. Although the augite is intensely altered to chlorite and montmorillonite, the plagioclase is nearly fresh. The less extensive alteration of this basalt as compared with volcaniclastic breccia clasts, its apparent enclosure by sediment, and its Miocene date (see Houghton et al., this volume), suggest that the basalt is a sill.

\section{Site 384, $J$-Anomaly Ridge}

Basaltic basement was penetrated to a depth of 5.5 meters, and 1.9 meters of hypocrystalline, fine-grained, amygdaloidal phyric basalt were recovered. The recovered section changes in color with depth from medium dark gray to dark yellowish to grayish brown and back to a grayish black. Contacts between these changes are greatly disrupted by drilling and intensified calcite veining. While three flows may be represented by this sequence, only variations in alteration are recognizable petrographically.

Common pyroxene $(0.4-2.0 \mathrm{~mm})$ and rare plagioclase phenocrysts $(0.5-0.8 \mathrm{~mm})$ lie in a pilotaxitic groundmass displaying minor fluxion of plagioclase microlites around phenocrysts and amygdules. Scarce patches of bowlingite suggest the former existence of olivine phenocrysts. The matrix consists of pyroxene $(10-20 \%)$ and poikilitic plagioclase $\left(\mathrm{An}_{70-75}\right)$ with 
scarce, partly devitrified brown glass. Secondary minerals are abundant, and numerous thin calcite veinlets $(0.02-0.1 \mathrm{~mm})$ with epidote-chlorite encrusted slickensides occur throughout. Elliptical vesicles $(<5 \mathrm{~mm})$ filled with calcite, montmorillonite, phillipsite, and scarce chlorite account for 10 to 25 per cent of the section. They are commonly lined with iron oxides and montmorillonite, possibly derived from devitrification of papagonite rims.

The uppermost color unit is distinguished by partial alteration of groundmass and phyric augite to montmorillonite with or without calcite. Alteration is most intense along cleavage planes where irregular bleaching is observed. Patches of magnetite sometimes line augite crystal boundaries. Groundmass plagioclase is altered to montmorillonite to the extent of 15 to 25 per cent.

The underlying brownish layer contains larger amounts of iron oxides which may account for its color. Plagioclase is less altered, though it is optically cloudy. Vesicles are completely filled with olive-green montmorillonite with lesser calcite and zeolite. Chlorite may locally be concentrated where veins intersect former vesicles.

The lowest basalt is little altered. Augite phenocrysts are clear, and only rarely partly altered to uralite, which occurs as single crystals or crystal aggregates with chlorite. Plagioclase phenocrysts are fresh, although groundmass feldspar is altered to montmorillonite where intersertal to pyroxene. Chlorite commonly mixes with montmorillonite to fill vesicles. Veins are common and contain abundant chlorite.

\section{Site 386, Central Bermuda Rise}

Mesozoic basement at Site 386 is a hypocrystalline, fine-grained, amygdaloidal phyric basalt. Common subhedral, prismatic plagioclase $\left(\mathrm{An}_{65-70} ; 0.097-0.87\right.$ $\mathrm{mm}$ ) and scarce, corroded, subangular pyroxene phenocrysts $(0.54-1.4 \mathrm{~mm})$ dot a groundmass of randomly oriented plagioclase microlites with intergranular pyroxene. Plagioclase phenocrysts are usually turbid from the effects of minor alteration and show the development of sericite, montmorillonite, or other clay minerals. The optic angle of pyroxene phenocrysts is variable, but is always less than $30^{\circ}$ and positive, suggesting compositions between pigeonite and subcalcic augite. This is also indicated by probe analyses presented in Table 2. Phenocrysts all show optical strain and incomplete extinction; these combine rarely to suggest an hour-glass pattern. Corrosion of early pyroxene phenocrysts suggests resorption, but is masked by alteration to montmorillonite and chlorite.

The groundmass consists mainly of a complex network of plagioclase $\left(\mathrm{An}_{67}\right)$ laths with interstitial granular pyroxene and lesser relict, locally subophitic glass. Alteration has preferentially affected the glass and fine groundmass and left the phenocrysts relatively fresh. All glass grains are partly to wholly devitrified, and most are extensively altered to clays. Angular interstitial areas and small rounded pools of montmorillonite and chlorite mark the sites of former glass and pyrox- ene. Remnant pyroxene grains appear to be compositionally similar to the phenocrysts. Occasional disseminated magnetite also appears as skeletal crystals in the groundmass. The freshest samples display a feathery texture in the groundmass, reminiscent of a feather duster, in which small microlites of plagioclase radiate from one end of a slightly larger plagioclase lath. True feather and plumose groundmass textures as described by Bryan (1972) from Site 105 were not found. Amygdules of calcite and/or montmorillonite account for less than 1 to 3 per cent of the cross-sectional area. Calcite stringers up to $0.04 \mathrm{~mm}$ wide are common.

Between 966.3 and 967.0 meters, the basalt is intersected by a segregation of calcite that is probably a hydrothermal vein. The vein is variously bounded by dense, slickensided lamellar coatings of chlorite and scarce serpentine, and by sharp, irregular contacts with the basalt. Basalt immediately adjacent to the vein shows an ordered alteration halo based on the intensity of chloritization. Up to $1 \mathrm{~cm}$ away from the vein, almost all the basalt groundmass is chloritized. For another $2 \mathrm{~cm}$, all vesicles are filled with chlorite instead of calcite. Beyond $3 \mathrm{~cm}$, only matrix pyroxene and glass show extensive alteration.

\section{Site 387, Western Bermuda Rise}

Apparent basement recovered at Site 387 is a grayish black, holocrystalline, fine-grained, amygdaloidal, phyric basalt characterized by a variable groundmass texture and by local enclosures of grayish red to dark reddish brown calcareous claystone. It is underlain by a thin, baked claystone. Phenocryst phases consist of common, partially corroded, subhedral, primatic plagioclase $\left(\mathrm{An}_{70-80} ; 0.072-3.24 \mathrm{~mm}\right)$ twinned according to the albite rule, and scarce, corroded, subangular pyroxene crystals. Slight alteration of plagioclase phenocrysts to montmorillonite and sericite give the crystals a turbid appearance. Pyroxene phenocrysts show a variable optic angle, but probably have compositions between pigeonite and subcalcic augite. Corroded phenocrysts of both phases show optical strain. The dearth of alteration products associated with corroded phenocrysts suggests the corrosion reflects resorption of these early formed crystals.

Dark glass occurs rarely throughout the uppermost $10 \mathrm{~cm}$ of basalt. An intensely fractured and chloritized zone 1.78 meters below the top of the basalt also bears glass. Elsewhere, the rock is holocrystalline.

Groundmass in all cases consists of a complex network of randomly oriented plagioclase $\left(\mathrm{An}_{65-76}\right)$ microlites with intergranular pyroxene and disseminated granular to skeletal magnetite. Although groundmass texture is variable throughout, the upper half meter of basalt is more fine grained. As the texture gradually coarsens downward, plagioclase microlites tend to congregate into crude crystal sprays. Secondary montmorillonite and chlorite partially obscure the texture within the intensely fractured zone at 793.68 meters. The underlying basalt is finer grained with combinations of feather duster (as described from Site 
386), true feather (Site 105; Bryan, 1972), variolitic, and shock or stook (Chapter 7) matrix textures.

Amygdules of calcite, montmorillonite, and chlorite, in decreasing order of importance, account for less than 1 per cent of the cross-sectional area. Chlorite is important only in the sheared zone. No local vesicle concentrations were noted. Calcite veins up to $3 \mathrm{~mm}$ in width are abundant in the upper 1.5 meters of basalt and common below.

Numerous enclosures of grayish red to dark reddish brown, slightly calcareous claystone occur throughout the basalt. Enclosures of similar sediment occur within calcite veins and appear to have been intruded into the basalt from below. The intruded sediment, a baked sediment contact, variable groundmass texture, textural gradation to a coarser interior, low vesicularity, and lack of glassy surfaces suggest the basalt is structurally a sill. This interpretation is uncertain, however, because similar features characterize flow sequences of ridge basalt cored during Leg 37.

\section{GEOCHEMISTRY}

Electron microprobe major element analyses of prepared unfluxed basalt glasses are given in Table 3. Trace element analyses by X-ray fluorescence and instrumental neutron activation are presented in Table 4. The elements in this table are divided into three sets: Set I-elements and oxides known to be sensitive indicators of alteration and reaction with seawater (Hart, 1969; Thompson, 1973); Set II-first series transition elements plus Ga; Set III (A and B)-large ion lithophile (LIL) elements.

Geochemically, the Leg 43 basalts subdivide naturally according to their tectonic environment. Basalts from the ocean basin (Sites 384, 386, and 387) are generally depleted in the LIL elements such as $\mathrm{K}$, Ti, $\mathrm{P}, \mathrm{Ba}, \mathrm{Sr}, \mathrm{Zr}$, and the light rare earth elements (LREE) when compared to island and continental tholeiitic basalts, a feature of many ocean ridge basalts (e.g., Engel et al., 1965; Melson et al., 1968; Frey et al., 1968; Hart, 1969; Kay et al., 1970; Frey et al., 1974). Volcanic rocks recovered from Sites 382 and 385 along the New England seamount chain, however, are strongly enriched in these elements. Although all samples are moderately to intensely altered, some immobile element concentrations display characteristics which may reflect magmatic processes.

\section{Sites 382 and 385}

The basalts of Nashville Seamount display far less geochemical than petrographic variability. All basalts are strongly LIL-element enriched and, save one, fall well within the alkali basalt field on plots of immobile element relationships such as $\mathrm{P}_{2} \mathrm{O}_{5}$ versus $\mathrm{TiO}_{2}$ (Figure 4, analyses $\mathrm{A}$ through $\mathrm{I}$ ) and $\mathrm{TiO}_{2}$ versus $\mathrm{Y}$ (Figure 5). Their Y concentrations alone, however, are comparable to those of the ocean basin basalts recovered at other sites. Plots of these basalt compositions on diagrams of $\mathrm{Sr}$ versus $\mathrm{TiO}_{2}$ (Figure 6) and $\mathrm{Zr}$ versus $\mathrm{Sr}$ (Figure 7) confirm the highly alkaline nature of these

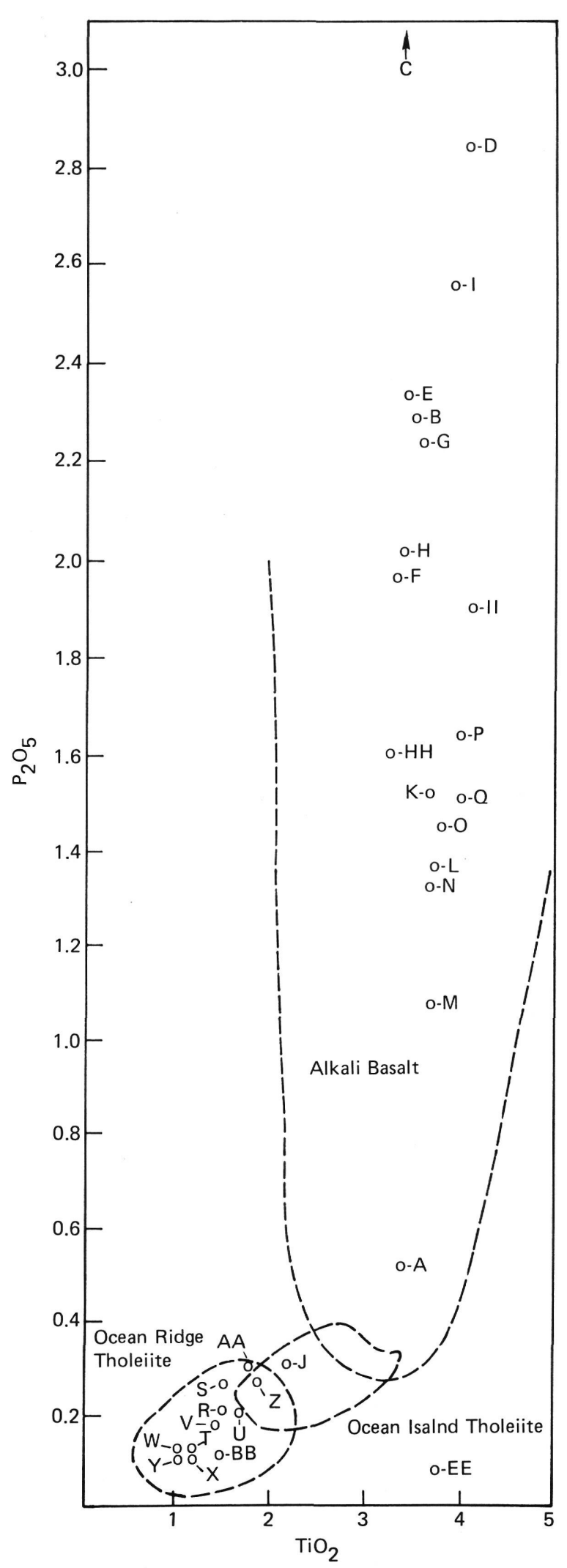

Figure 4. $\mathrm{P}_{2} \mathrm{O}_{5}$ versus $\mathrm{TiO}_{2}$ immobile element discrimination diagram (after Bass et al., 1973). Letter designations for specific basalt analyses are from Tables 3 and 4. 
TABLE 3

Major Element Composition of DSDP Leg 43 Basalts (in wt \%)

\begin{tabular}{|c|c|c|c|c|c|c|c|c|c|c|c|c|c|c|}
\hline & (A) & (B) & $(C)$ & (D) & (E) & $(\mathrm{F})$ & (G) & $(\mathrm{H})$ & (I) & $(\mathrm{J})$ & $(\mathrm{K})$ & (L) & $(\mathrm{M})$ & $(\mathrm{N})$ \\
\hline $\mathrm{SiO}_{2}$ & 47.02 & 35.02 & 35.33 & 46.85 & 44.31 & 35.14 & 46.02 & 44.16 & 36.27 & 44.67 & 40.06 & 40.38 & 40.63 & 40.72 \\
\hline $\mathrm{Al}_{2} \mathrm{O}_{3}$ & 15.60 & 13.54 & 13.56 & 12.53 & 13.50 & 13.76 & 13.35 & 13.63 & 12.93 & 14.49 & 11.60 & 12.79 & 12.70 & 12.90 \\
\hline $\mathrm{FeO}^{*}$ & 9.63 & 9.42 & 10.52 & 11.28 & 11.03 & 10.45 & 12.10 & 12.04 & 9.90 & 12.61 & 9.63 & 9.90 & 10.40 & 9.68 \\
\hline $\mathrm{MgO}$ & 4.81 & 7.95 & 7.48 & 10.25 & 7.83 & 6.08 & 7.39 & 6.53 & 10.35 & 7.13 & 3.34 & 3.99 & 4.75 & 5.83 \\
\hline $\mathrm{CaO}$ & 9.07 & 9.68 & 7.05 & 5.14 & 9.15 & 10.06 & 7.41 & 9.65 & 6.39 & 6.66 & 12.78 & 10.91 & 10.99 & 11.17 \\
\hline $\mathrm{Na}_{2} \mathrm{O}$ & 2.92 & 2.21 & 2.59 & 2.21 & 2.33 & 3.35 & 3.04 & 3.58 & 2.01 & 3.41 & 1.39 & 1.80 & 1.68 & 1.64 \\
\hline $\mathrm{K}_{2} \mathrm{O}$ & 0.89 & 1.12 & 1.33 & 2.08 & 1.96 & 0.77 & 2.16 & 1.69 & 1.26 & 0.46 & 4.60 & 4.11 & 2.91 & 2.86 \\
\hline $\mathrm{TiO}_{2}$ & 3.31 & 3.25 & 3.38 & 3.91 & 3.28 & 3.13 & 3.41 & 3.18 & 3.89 & 2.12 & 3.76 & 3.69 & 3.56 & 3.67 \\
\hline $\mathrm{MnO}$ & 0.45 & 0.33 & 0.47 & 0.41 & 0.13 & 0.27 & 0.16 & 0.08 & 0.82 & 0.40 & 0.15 & 0.21 & 0.25 & 0.18 \\
\hline $\mathrm{P}_{2} \mathrm{O}_{5}$ & 0.52 & 2.30 & 3.24 & 2.87 & 2.36 & 1.97 & 2.25 & 2.01 & 2.55 & 0.33 & 1.50 & 1.36 & 1.04 & 1.32 \\
\hline $\mathrm{H}_{2} \mathrm{O}^{+}$ & 2.22 & 4.11 & 4.83 & 0.69 & 1.64 & 4.78 & 1.31 & 1.54 & 3.88 & 2.93 & 4.07 & 3.82 & 3.44 & 3.63 \\
\hline $\mathrm{H}_{2} \mathrm{O}^{-}$ & 3.08 & 8.13 & 7.88 & 1.36 & 2.81 & 7.59 & 1.77 & 1.93 & 6.02 & 4.12 & 5.73 & 5.52 & 5.67 & 4.88 \\
\hline $\mathrm{CO}_{2}$ & 0.91 & 2.20 & 2.32 & 0.44 & 0.57 & 2.18 & 0.51 & 0.66 & 1.72 & 0.45 & 1.38 & 1.33 & 1.31 & 1.30 \\
\hline Total & 100.05 & 100.06 & 99.98 & 100.02 & 99.90 & 100.39 & 99.91 & 99.98 & 98.97 & 99.79 & 99.96 & 99.80 & 99.33 & 99.78 \\
\hline \multirow[t]{2}{*}{$\mathrm{FeO}^{*} / \mathrm{MgO}$} & 2.00 & 1.18 & 1.41 & 1.10 & 1.41 & 1.72 & 1.64 & 1.84 & 0.96 & 1.77 & 2.88 & 2.48 & 2.19 & 1.66 \\
\hline & $(\mathrm{O})$ & $(\mathrm{P})$ & $(\mathrm{Q})$ & (R) & (S) & $(\mathrm{T})$ & (U) & (V) & (W) & $(\mathrm{X})$ & $(\mathrm{Y})$ & $(\mathrm{Z})$ & $(\mathrm{AA})$ & \\
\hline $\mathrm{SiO}_{2}$ & 40.74 & 41.16 & 42.01 & 49.9 & 48.1 & 46.73 & 49.99 & 44.56 & 46.12 & 45.59 & 44.36 & 45.29 & 43.38 & \\
\hline $\mathrm{Al}_{2} \mathrm{O}_{3}$ & 11.46 & 11.67 & 11.60 & 16.9 & 17.1 & 15.72 & 15.25 & 15.61 & 13.46 & 14.80 & 13.05 & 13.12 & 13.85 & \\
\hline $\mathrm{FeO}^{*}$ & 9.63 & 9.80 & 9.77 & 9.3 & 9.5 & 7.24 & 6.99 & 8.48 & 7.57 & 8.18 & 10.09 & 10.65 & 10.93 & \\
\hline $\mathrm{MgO}$ & 6.42 & 6.95 & 6.63 & 6.6 & 6.2 & 6.02 & 7.11 & 5.81 & 8.85 & 7.16 & 6.87 & 10.19 & 9.76 & \\
\hline $\mathrm{CaO}$ & 11.98 & 11.21 & 12.03 & 11.8 & 11.0 & 6.80 & 6.76 & 6.42 & 11.43 & 12.05 & 11.13 & 9.61 & 8.98 & \\
\hline $\mathrm{Na}_{2} \mathrm{O}$ & 1.33 & 1.26 & 1.46 & 2.61 & 2.58 & 2.20 & 2.58 & 1.50 & 2.15 & 2.61 & 1.86 & 2.49 & 2.61 & \\
\hline $\mathrm{K}_{2} \mathrm{O}$ & 3.71 & 3.83 & 2.89 & 0.49 & 0.53 & 1.33 & 1.35 & 1.59 & 0.09 & 0.11 & 0.23 & 0.22 & 0.28 & \\
\hline $\mathrm{TiO}_{2}$ & 3.74 & 4.02 & 3.82 & 1.48 & 1.50 & 1.19 & 1.68 & 1.42 & 1.03 & 1.16 & 1.10 & 1.81 & 1.79 & \\
\hline $\mathrm{MnO}$ & 0.16 & 0.20 & 0.37 & 0.11 & 0.12 & 0.11 & 0.04 & 0.14 & 0.08 & 0.17 & 0.09 & 0.13 & 0.15 & \\
\hline $\mathrm{P}_{2} \mathrm{O}_{5}$ & 1.45 & 1.63 & 1.52 & 0.21 & 0.26 & 0.13 & 0.21 & 0.18 & 0.13 & 0.12 & 0.12 & 0.28 & 0.30 & \\
\hline $\mathrm{H}_{2} \mathrm{O}^{+}$ & 3.27 & 2.75 & 2.21 & - & (c) & 5.03 & 2.89 & 5.47 & 3.93 & 3.23 & 4.88 & 2.76 & 3.01 & \\
\hline $\mathrm{H}_{2}^{-} \mathrm{O}^{-}$ & 4.51 & 3.87 & 4.01 & - & 3.31 & 6.09 & 3.86 & 6.81 & 4.88 & 4.47 & 5.36 & 3.04 & 3.62 & \\
\hline $\mathrm{CO}_{2}$ & 1.24 & 1.22 & 1.21 & - & - & 1.39 & 1.21 & 1.99 & 0.20 & 0.16 & 0.96 & 0.73 & 1.32 & \\
\hline Total & 99.64 & 99.57 & 99.53 & 99.18 & 96.63 & 99.98 & 99.92 & 100.04 & 99.92 & 99.81 & 100.10 & 100.32 & 99.98 & \\
\hline $\mathrm{FeO}^{*} / \mathrm{MgO}$ & 1.50 & 1.41 & 1.28 & 1.41 & 1.42 & 1.20 & 0.98 & 1.46 & 0.86 & 1.14 & 1.47 & 1.05 & 1.12 & \\
\hline
\end{tabular}

Note: (A) 382-23-1, 98-102 cm, type 2; (B) 382-23-1, 134-139 cm; (C) 382-23-3, 113-116 cm; (D) 382-24-1, 118-124 cm, type 1; (E) 382-24-1, 120$126 \mathrm{~cm}$, type 3; (F) 382-24-2, 63-67 cm; (G) 382-25-1, 129-131 cm; (H) 382-25-2, 91-95 cm, type 4; (I) 382-25-2, 146-149 cm; (J) 382-25-2, 125$130 \mathrm{~cm}$, type 5; (K) 385-23-1, 139-145 cm; (L) 385-20-2, 80-91 cm; (M) 385-23-2, 129-132 cm; (N) 385-23-3, 126-129 cm; (O) 385-24-1, 49-54 cm; (P) 385-20-2, 112-118 cm; (Q) 385-20, CC (11-15 cm); (R) 385-16, CC (8 cm) (core); (S) 385-16, CC (8 cm) (margin); (T) 384-22-2, 127-129 cm; (U) 384-22, CC (146-148 cm); (V) 384-22-1, 118-120 cm; (W) 386-66-2, 128-132 cm; (X) 386-66, CC (13-15 cm); (Y) 386-66-1, 1-4 cm; (Z) 387-50-2, $134-137 \mathrm{~cm}$; (AA) $387-50-1,98-101 \mathrm{~cm}$.

lavas. Sr concentrations are occasionally less than their corresponding $\mathrm{Zr}$ and $\mathrm{TiO}_{2}$ values would suggest (e.g., samples $\mathrm{C}, \mathrm{D}, \mathrm{I})$. While this relationship is consistent with the findings of Bass et al. (1973) that intense diagenetic alteration decreases the $\mathrm{Sr}$ content of basalts, it is curious that the most intensely altered samples (highest $\mathrm{H}_{2} \mathrm{O}$ contents and $\mathrm{Fe}_{2} \mathrm{O}_{3} / \mathrm{FeO}$ ratios) in this collection fall well within the alkali fields on the above diagrams.

Clinopyroxene- and olivine-bearing basalts (type 1) are relatively lower in $\mathrm{Co}, \mathrm{Ni}$, and $\mathrm{Cr}$ (Table 4) than their companion types. Type 1 basalt also displays a small negative Eu anomaly (Figure 8, analysis D) in its chondrite-normalized REE pattern. Clinopyroxeneamphibole basalt appears to be relatively depleted in Sc and $\mathrm{V}$ and shows a small, negative Eu anomaly (Figure 8, analysis A) like that discussed above. Plagioclase-clinopyroxene phyric basalts and aphanitic basalt at Site 382 are chemically similar; both show small positive $\mathrm{Eu}$ anomalies (Figure 8 analyses $\mathrm{E}$ and $\mathrm{H}$ ).

A single sample from the New England seamount sites shows characteristics of an oceanic island tholeiite (Figures 4, 6, and 7 analysis $\mathrm{J}$ ). $\mathrm{TiO}_{2}$ versus $\mathrm{Y}$ relations (Figure 5), however, suggest it may also be an alkali basalt. Except for a slightly lower concentration of the
LIL minor elements (e.g., K, Ti, P), alteration masks any major element distinction from its neighboring alkali basalts. The basalt is relatively enriched in Co, but not $\mathrm{Ni}$ with respect to other New England seamount basalts. A slight LREE enrichment (Figure 9) may be due in part to alteration, but the tholeiite is unquestionably LIL-element enriched. The unusual positive $\mathrm{Ho}$ anomaly could be an alteration effect or a primary characteristic of the lava. The basalt also shows a minor positive Eu anomaly.

Basalts recovered on the flank of Vogel Seamount at Site 385 are all type 3 and 4 alkali basalts (Figure 4 through 7 , analyses $\mathrm{K}-\mathrm{Q}$ ). While the higher $\mathrm{K}_{2} \mathrm{O}$ and lower $\mathrm{Na}_{2} \mathrm{O}$ values of these basalts with respect to the Nashville lavas may be due to alteration (Hart, 1969), increased $\mathrm{CaO}$ concentrations are probably characteristic of the system. Of the trace elements analyzed, only Co appears to be systematically depleted. As for the Site 382 basalts, Vogel lavas may bear less $\mathrm{Sr}$ than $\mathrm{Zr}$ (Figure 7) and $\mathrm{TiO}_{2}$ (Figure 6) concentrations would indicate (e.g., sample $\mathrm{K}, \mathrm{O}, \mathrm{P}, \mathrm{Q}$ ). In accord with the more intense alteration of these rocks, their LREE patterns are significantly more enriched. Positive Eu anomalies match those of the same basalt type on Nashville but are slightly more pronounced. 
TABLE 4

Trace Element, $\mathrm{H}_{2} \mathrm{O}$, and $\mathrm{CO}_{2}$ Abundances and $\mathrm{Fe}_{2} \mathrm{O}_{3} / \mathrm{FeO}$ Ratios of DSDP Leg 43 Basalts

\begin{tabular}{|c|c|c|c|c|c|c|c|c|c|c|c|c|c|c|}
\hline & (A) & (B) & $(\mathrm{C})$ & (D) & (E) & $(\mathrm{F})$ & $(\mathrm{G})$ & $(\mathrm{H})$ & (I) & $(\mathrm{J})$ & $(\mathrm{K})$ & (L) & (M) & $(\mathrm{N})$ \\
\hline \multicolumn{15}{|l|}{ Set I } \\
\hline $\mathrm{H}_{2} \mathrm{O}$ & 5.30 & 12.24 & 12.71 & 2.05 & 4.45 & 12.37 & 3.08 & 3.47 & 9.90 & 7.05 & 9.80 & 9.34 & 9.11 & 8.51 \\
\hline $\mathrm{CO}_{2}$ & 0.91 & 2.20 & 2.32 & 0.44 & 0.57 & 2.18 & 0.51 & 0.66 & 1.72 & 0.45 & 1.38 & 1.33 & 1.31 & 1.30 \\
\hline $\mathrm{Fe}_{2} \mathrm{O}_{3} / \mathrm{FeO}$ & 4.87 & 78.9 & 92.6 & 1.68 & 2.97 & 58.7 & 1.99 & 2.63 & 12.3 & 0.84 & 12.1 & 10.7 & 9.87 & 9.23 \\
\hline $\mathrm{K}_{2} \mathrm{O}$ & 0.89 & 1.12 & 1.33 & 2.08 & 1.96 & 0.77 & 2.16 & 1.69 & 1.26 & 0.46 & 4.60 & 4.11 & 2.91 & 2.86 \\
\hline \multicolumn{15}{|l|}{ Set II } \\
\hline $\mathrm{Sc}$ & 23 & 33 & 35 & 30 & 29 & 31 & 28 & 30 & 31 & 32 & 26 & 22 & 27 & 28 \\
\hline $\mathrm{V}$ & 200 & 320 & 344 & 331 & 384 & 376 & 408 & 393 & 415 & 264 & 404 & 401 & 392 & 387 \\
\hline $\mathrm{Cr}$ & 254 & 277 & 299 & 224 & 301 & 306 & 286 & 298 & 310 & 112 & 281 & 275 & 259 & 252 \\
\hline $\mathrm{Co}$ & 48 & 51 & 50 & 32 & 46 & 48 & 37 & 42 & 45 & 54 & 35 & 34 & 28 & 30 \\
\hline $\mathrm{Ni}$ & 106 & 134 & 156 & 85 & 173 & 148 & 154 & 165 & 162 & 73 & 157 & 151 & 148 & 147 \\
\hline $\mathrm{Cu}$ & 55 & 69 & 65 & 67 & 66 & 59 & 67 & 54 & 63 & 72 & 68 & 71 & 65 & 70 \\
\hline $\mathrm{Zn}$ & 103 & 125 & 117 & 87 & 108 & 122 & 128 & 125 & 120 & 110 & 126 & 113 & 119 & 133 \\
\hline $\mathrm{Ga}$ & n.d. & n.d. & n.d. & n.d. & n.d. & n.d. & n.d. & n.d. & n.d. & n.d. & n.d. & n.d. & n.d. & n.d. \\
\hline \multicolumn{15}{|l|}{ Set IIIA } \\
\hline $\mathrm{Sr}$ & 480 & 545 & 410 & 320 & 505 & 540 & 425 & 550 & 335 & 280 & 405 & 475 & 495 & 420 \\
\hline $\mathrm{Ba}$ & 512 & 492 & 439 & 365 & 456 & 501 & 531 & 470 & 397 & 218 & 534 & 539 & 553 & 547 \\
\hline $\mathrm{Y}$ & 26 & 32 & 30 & 24 & 30 & 31 & 27 & 31 & 32 & 41 & 24 & 26 & 26 & 24 \\
\hline $\mathrm{Zr}$ & 283 & 246 & 322 & 314 & 270 & 378 & 326 & 333 & 382 & 152 & 352 & 338 & 322 & 324 \\
\hline $\mathrm{Hf}$ & n.d. & n.d. & n.d. & n.d. & n.d. & n.d. & n.d. & n.d. & n.d. & n.d. & n.d. & n.d. & n.d. & n.d. \\
\hline $\mathrm{Ta}$ & n.d. & n.d. & n.d. & n.d. & n.d. & n.d. & n.d. & n.d. & n.d. & n.d. & n.d. & n.d. & n.d. & n.d. \\
\hline \multicolumn{15}{|l|}{ Set IIIB } \\
\hline $\mathrm{La}$ & 24.8 & n.d. & n.d. & 26.5 & 21.2 & n.d. & n.d. & 30.4 & n.d. & 9.93 & 46.0 & 39.2 & 29.8 & 23.8 \\
\hline $\mathrm{Ce}$ & 56.8 & n.d. & n.d. & 60.1 & 49.4 & n.d. & n.d. & 64.9 & n.d. & 21.3 & 83.8 & 70.1 & 58.8 & 52.6 \\
\hline $\mathrm{Nd}$ & 25.4 & n.d. & n.d. & 27.4 & 21.0 & n.d. & n.d. & 25.1 & n.d. & 13.4 & 21.2 & 24.0 & 19.3 & 23.3 \\
\hline $\mathrm{Sm}$ & 5.21 & n.d. & n.d. & 5.54 & 4.42 & n.d. & n.d. & 4.81 & n.d. & 3.40 & 4.31 & 3.84 & 4.22 & 4.00 \\
\hline $\mathrm{Eu}$ & 1.46 & n.d. & n.d. & 1.59 & 2.13 & n.d. & n.d. & 2.00 & n.d. & 1.32 & 2.01 & 1.64 & 1.72 & 1.93 \\
\hline $\mathrm{Tb}$ & 0.860 & n.d. & n.d. & 0.874 & 0.761 & n.d. & n.d. & 0.973 & n.d. & 0.719 & 0.658 & 0.700 & 0.752 & 0.625 \\
\hline Ho & 0.833 & n.d. & n.d. & 0.959 & 0.896 & n.d. & n.d. & 1.06 & n.d. & 1.16 & 0.672 & 0.791 & 0.763 & 0.707 \\
\hline $\mathrm{Yb}$ & 1.64 & n.d. & n.d. & 1.93 & 2.02 & n.d. & n.d. & 2.40 & n.d. & 2.16 & 1.30 & 1.68 & 1.44 & 1.42 \\
\hline $\mathrm{Lu}$ & 0.314 & n.d. & n.d. & 0.347 & 0.360 & n.d. & n.d. & 0.381 & n.d. & 0.364 & 0.292 & 0.292 & 0.309 & 0.255 \\
\hline $\mathrm{La} / \mathrm{Sm}$ & 4.76 & - & - & 4.78 & 4.80 & - & - & 6.32 & - & 2.92 & 10.7 & 10.2 & 7.06 & 5.95 \\
\hline \multirow[t]{2}{*}{ Basalt type } & 2 & & & 1 & 3 & & & 4 & & 5 & & & & \\
\hline & $(\mathrm{O})$ & (P) & $(\mathrm{Q})$ & (R) & (S) & $(\mathrm{T})$ & (U) & (V) & (W) & $(\mathrm{X})$ & $(\mathrm{Y})$ & $(Z)$ & (AA) & \\
\hline \multicolumn{15}{|l|}{ Set I } \\
\hline $\mathrm{H}_{2} \mathrm{O}$ & 7.78 & 6.63 & 6.22 & 1.07 & 3.37 & 11.12 & 6.75 & 12.28 & 8.81 & 7.70 & 10.24 & 5.80 & 6.63 & \\
\hline $\mathrm{CO}_{2}$ & 1.24 & 1.22 & 1.21 & n.d. & n.d. & 1.39 & 1.21 & 1.99 & 0.20 & 0.16 & 0.96 & 0.73 & 1.32 & \\
\hline $\mathrm{Fe}_{2} \mathrm{O}_{3} / \mathrm{FeO}$ & 8.03 & 5.63 & 5.04 & 1.96 & n.d. & 9.76 & 6.21 & 12.1 & 5.13 & 5.68 & 9.86 & 5.15 & 7.21 & \\
\hline $\mathrm{K}_{2} \mathrm{O}$ & 3.71 & 3.83 & 2.89 & 0.49 & 0.53 & 1.33 & 1.35 & 1.59 & 0.09 & 0.11 & 0.23 & 0.22 & 0.28 & \\
\hline \multicolumn{15}{|l|}{ Set II } \\
\hline $\mathrm{Sc}$ & 24 & 26 & 29 & 42 & n.d. & 29 & 36 & 28 & 34 & 35 & 32 & 37 & 38 & \\
\hline $\mathrm{V}$ & 373 & 378 & 358 & 240 & n.d. & 213 & 195 & 218 & 188 & 152 & 196 & 127 & 132 & \\
\hline $\mathrm{Cr}$ & 241 & 222 & 215 & n.d. & n.d. & 621 & 429 & 642 & 412 & 346 & 461 & 319 & 349 & \\
\hline Co & 33 & 37 & 29 & n.d. & n.d. & 29 & 39 & 31 & 38 & 26 & 25 & 23 & 24 & \\
\hline $\mathrm{Ni}$ & 142 & 139 & 136 & n.d. & n.d. & 269 & 219 & 265 & 157 & 152 & 171 & 110 & 100 & \\
\hline $\mathrm{Cu}$ & 54 & 62 & 66 & n.d. & n.d. & 77 & 65 & 81 & 68 & 56 & 65 & 120 & 71 & \\
\hline $\mathrm{Zn}$ & 129 & 133 & 120 & n.d. & n.d. & 165 & 99 & 182 & 84 & 79 & 112 & 85 & 93 & \\
\hline $\mathrm{Ga}$ & n.d. & n.d. & n.d. & 15 & n.d. & n.d. & n.d. & n.d. & n.d. & n.d. & n.d. & n.d. & n.d. & \\
\hline \multicolumn{15}{|l|}{ Set IIIA } \\
\hline $\mathrm{Sr}$ & 390 & 365 & 410 & 365 & 385 & 167 & 7 & 165 & 146 & 195 & 216 & 84 & 339 & \\
\hline $\mathrm{Ba}$ & 576 & 585 & 591 & n.d. & n.d. & 141 & 97 & 158 & 146 & 96 & 161 & 111 & 104 & \\
\hline $\mathrm{Y}$ & 24 & 26 & 20 & 23 & n.d. & 38 & 42 & 36 & 24 & 34 & 30 & 20 & 23 & \\
\hline $\mathrm{Zr}$ & 362 & 378 & 316 & 170 & 174 & 147 & 189 & 164 & 95 & 114 & 86 & 81 & 103 & \\
\hline $\mathrm{Hf}$ & n.d. & n.d. & n.d. & 3.25 & n.d. & 1.98 & 1.46 & 1.87 & 1.16 & 1.34 & 1.83 & n.d. & n.d. & \\
\hline $\mathrm{Ta}$ & n.d. & n.d. & n.d. & 4.1 & n.d. & n.d. & n.d. & n.d. & 0.33 & n.d. & 0.28 & n.d. & n.d. & \\
\hline Set IIIB & & & & & & & & & & & & & & \\
\hline $\mathrm{La}$ & 26.4 & 16.5 & 13.3 & 11.7 & n.d. & 5.91 & 6.20 & 6.60 & 3.10 & 3.33 & 3.96 & 3.04 & 2.80 & \\
\hline $\mathrm{Ce}$ & 52.6 & 42.4 & 29.2 & 30.1 & n.d. & 13.99 & 19.3 & 18.6 & 10.6 & 12.3 & 14.2 & 8.77 & 7.46 & \\
\hline $\mathrm{Nd}$ & 15.1 & 16.4 & 14.9 & 15.2 & n.d. & 13.3 & 13.8 & 12.5 & 8.52 & 11.9 & 10.7 & 6.48 & 6.72 & \\
\hline $\mathrm{Sm}$ & 3.57 & 3.64 & 3.44 & 3.5 & n.d. & 5.77 & 5.39 & 4.51 & 3.20 & 4.20 & 3.44 & 2.10 & 2.30 & \\
\hline $\mathrm{Eu}$ & 1.32 & 2.23 & 1.44 & 1.3 & n.d. & 1.30 & 1.30 & 1.46 & 0.987 & 1.30 & 1.01 & 0.670 & 0.800 & \\
\hline $\mathrm{Tb}$ & 0.658 & 0.691 & 0.503 & 0.75 & n.d. & 0.987 & 1.08 & 0.931 & 0.653 & 0.935 & 0.818 & 0.517 & 0.564 & \\
\hline Ho & 0.721 & 0.812 & 0.651 & 0.73 & n.d. & 1.18 & 1.34 & 1.13 & 0.756 & 1.00 & 0.917 & 0.607 & 0.791 & \\
\hline $\mathrm{Yb}$ & 1.28 & 1.82 & 1.52 & 1.67 & n.d. & 2.48 & 2.90 & 2.66 & 1.50 & 2.10 & 1.72 & 1.30 & 2.12 & \\
\hline $\mathrm{Lu}$ & 0.279 & 0.303 & 0.279 & 0.30 & n.d. & 0.564 & 0.530 & 0.500 & 0.244 & 0.333 & 0.279 & 0.258 & 0.374 & \\
\hline $\mathrm{La} / \mathrm{Sm}$ & 7.39 & 4.53 & 3.87 & 3.34 & - & 1.02 & 1.15 & 1.46 & 0.969 & 0.793 & 1.15 & 1.45 & 1.22 & \\
\hline
\end{tabular}

$\mathrm{H}_{2} \mathrm{O}, \mathrm{CO}_{2}$, and $\mathrm{K}_{2} \mathrm{O}$ are in weight percent; all other values are in ppm.

For technique, accuracy, and precision see "Analytical Techniques."

Note: n.d., not determined, indicates not analyzed for. See Table 3 for sample designations.

The basaltic sill is considerably less altered than the volcanic clasts of the underlying tuff breccia. Chemically (Tables 3 and 4, analyses $\mathbf{R}$ and S), it is strikingly similar to a sill of like age (see Houghton et al., this volume) from Site 10 (Table 5, analysis DD) analyzed by Frey et al. (1974). Immobile element diagrams show both to be similarly enriched oceanic island tholeiites (Figure 5 through 7). In both cases, however, 


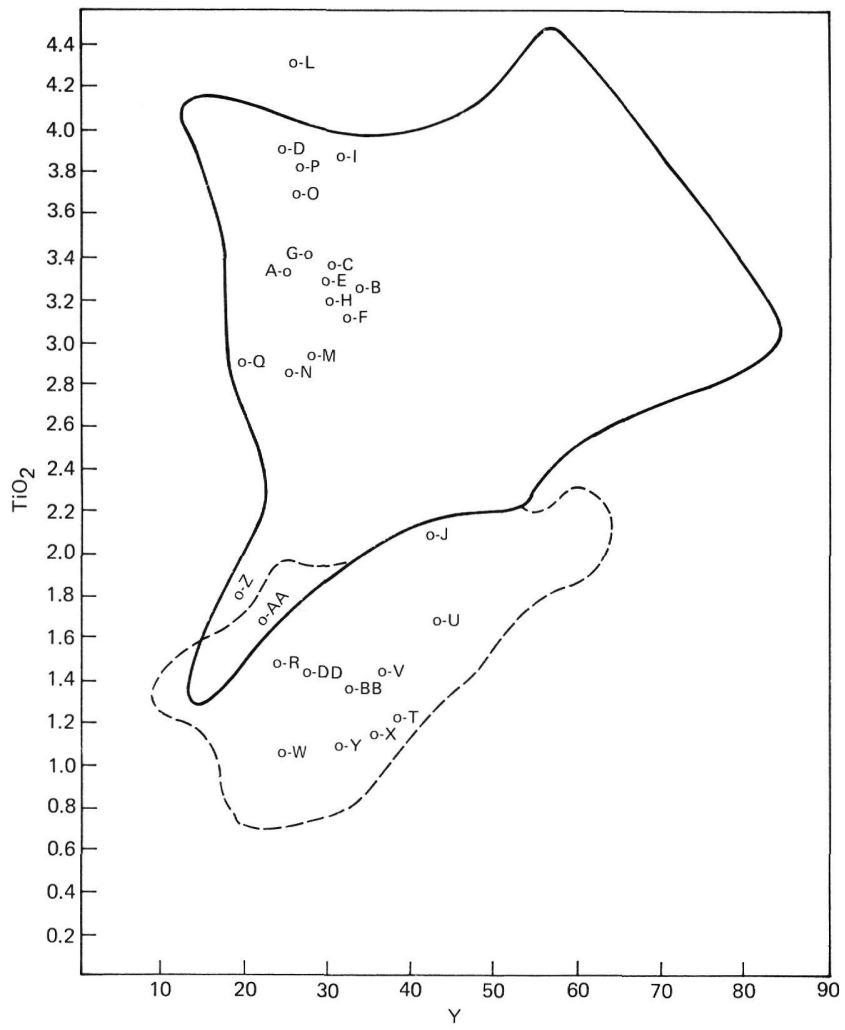

Figure 5. $\mathrm{TiO}_{2}$ versus $Y$ immobile element discrimination diagram. Solid line encloses field of oceanic alkalic basalts as determined from analyses presented in Nockolds and Allen (1954); LeMaitre (1962); Engel et al. (1965); Baker (1969); Flower (1973); and Gass et al. (1973). Dashed line encloses field of oceanic tholeiites as determined from data in Muir and Tilley (1964); Engel et al. (1965); Cann (1970, 1971); Melson and Thompson (1971); Gass et al. (1973); and Baker et al. (1974).

low $\mathrm{TiO}_{2}$ concentrations cause them to plot as oceanic ridqe tholeiites on $\mathrm{P}_{2} \mathrm{O}_{5}$ versus $\mathrm{TiO}_{2}$ diagrams (Figure 4). REE patterns (Figure 10) of these basalts are similarly LREE enriched and lack significant anomalies.

\section{Sites 384, 386, 387}

Basalt recovered at Site 384 is moderately to intensely altered as indicated by high $\mathrm{H}_{2} \mathrm{O}$ concentrations and $\mathrm{Fe}_{2} \mathrm{O}_{3} / \mathrm{FeO}$ ratios (Tables 4 , analyses $\mathrm{T}$ through V). Immobile element diagrams (Figures 4 through 7 ) show the lava to be typical of oceanic ridge tholeiite. Compared to an average MAR tholeiite (Tables 5, analysis BB), basalt recovered on $J$ anomaly Ridge is somewhat enriched in K. LREE's (Figure 11) are slightly enriched as compared to average Mid-Atlantic Ridge basalt, in part possibly as a result of the effects of alteration. The basalt shows a negative Eu anomaly. An up-core intensification of alteration is reflected in LREE, Cr, V, $\mathrm{Zn}, \mathrm{Ba}$, and $\mathrm{Sr}$ enrichments, the last is particularly marked because of its anomalously low initial composition.

Oceanic basement of Site 386 on the central Bermuda Rise is a moderately altered, LIL-depleted

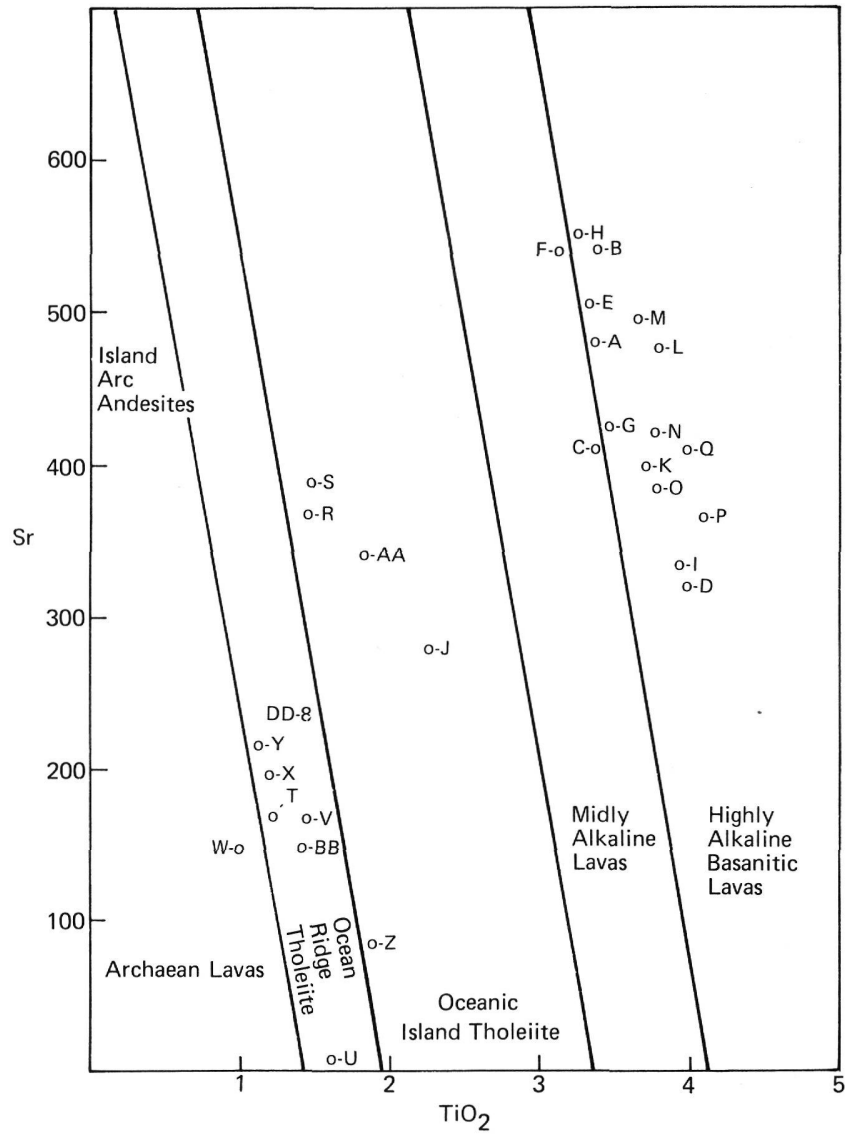

Figure 6. $\mathrm{Sr}$ versus $\mathrm{TiO}_{2}$ discrimination diagram of Leg 43 basalts (after Gunn and Watkins, 1976). Letter designations for specific basalt analyses are from Tables 3 and 4.

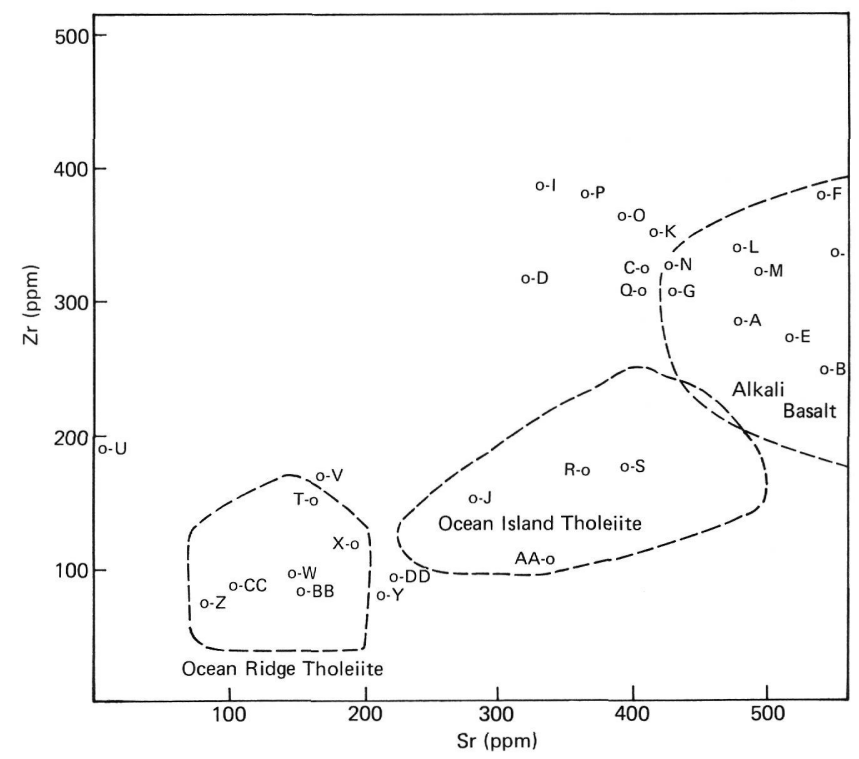

Figure 7. $\mathrm{Zr}$ versus $\mathrm{Sr}$ discrimination diagram for Leg 43 basalts (after Bass et al., 1973). Letter designations for specific basalt analyses are from Table 4.

tholeiite (Tables 3 and 4, analyses $\mathrm{W}$ through $\mathrm{Y}$ ) typical of oceanic ridge basalts (Figures 4 through 7). The relatively low $\mathrm{CO}_{2}$ concentrations reported reflect 


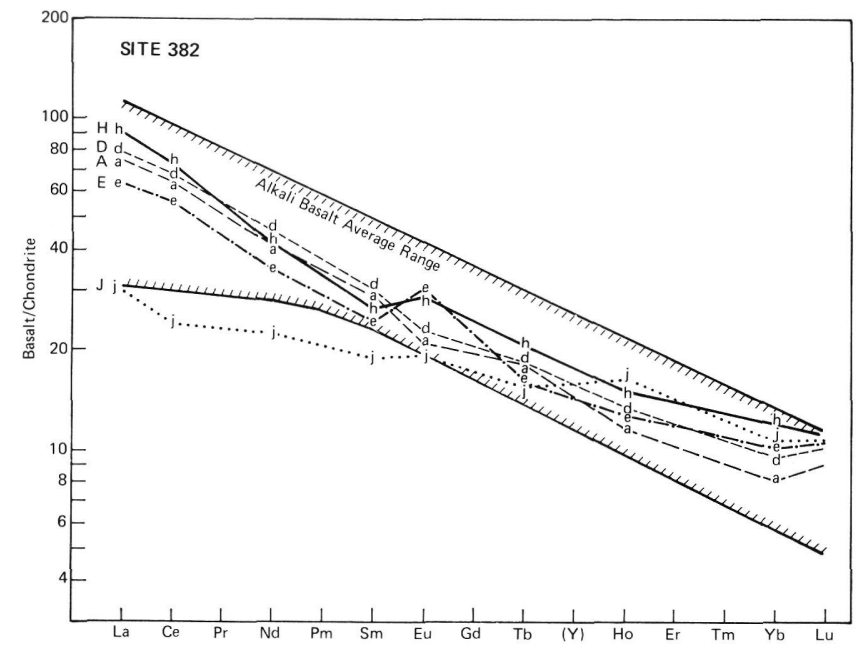

Figure 8. REE abundances in Leg 43, Site 382, basalts compared to a chondritic average (Frey et al., 1968). The range of average oceanic island alkalic basalts is from Frey et al. (1974). Letter designations for specific basalt analyses are from Table 4.

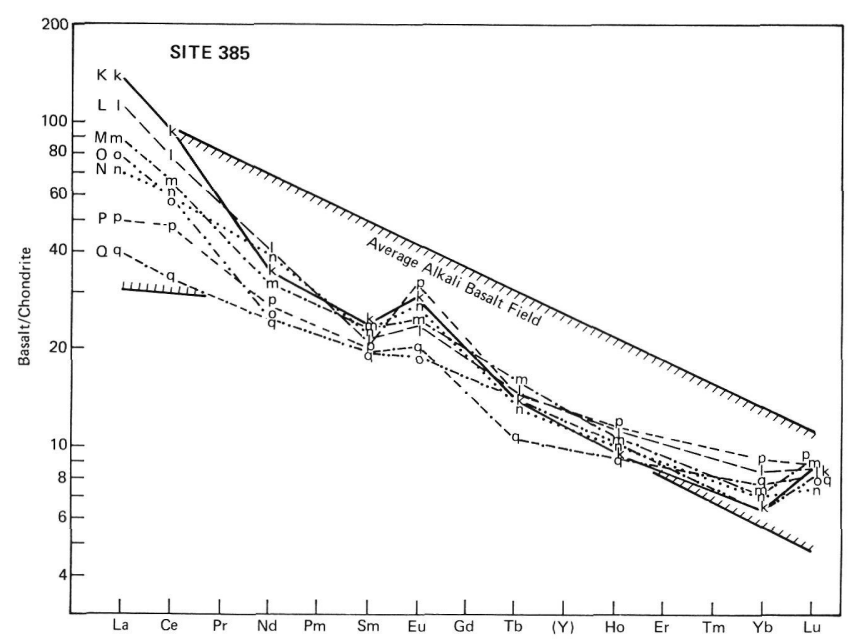

Figure 9. REE abundances in Site 385 basalts compared to a chondritic average. Letter designations for specific basalt analyses are from Table 4.

a concerted effort not to analyze vein calcite in the basalts. LREE's (Figure 12) are slightly depleted and show a minor negative Eu anomaly. As at Site 384, enrichment of $\mathrm{Cr}, \mathrm{V}, \mathrm{Zn}, \mathrm{Sr}$, and $\mathrm{Ba}$ parallels up-core increase of alteration. Ba concentrations are very high, enriched by a factor of five compared to average MidAtlantic Ridge basalt (Table 5, analysis BB). If this enrichment is due to alteration, other trace elements could be enriched by similar amounts.

Basalt recovered at Site 387 (Tables 3 and 4, analyses $\mathrm{Z}$ and $\mathrm{AA}$ ) on the western Bermuda Rise was interpreted petrographically (this report) and structurally (Chapter 7) as a sill. However LREE's are depleted and the entire REE concentrations fall below Mid-Atlantic Ridge basalt averages (Figure 13). A slight negative $\mathrm{Eu}$ anomaly is shown. Immobile ele-

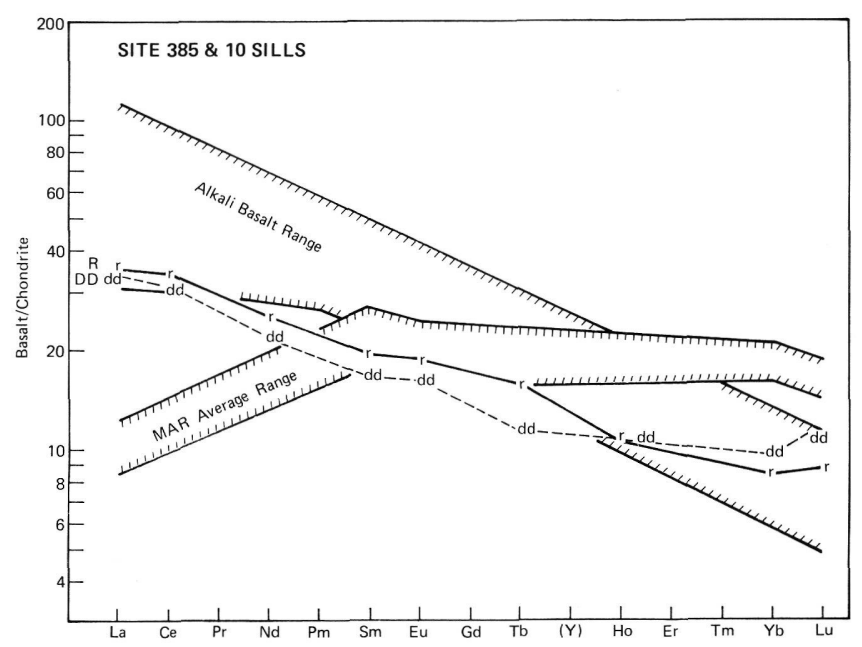

Figure 10. REE abundances of Leg 43, Site 385, and Leg 2, Site 10 (Frey et al., 1974) sill basalts compared to a chondritic average. Letter designations for specific basalt analyses are from Tables 4 and $5 b$.

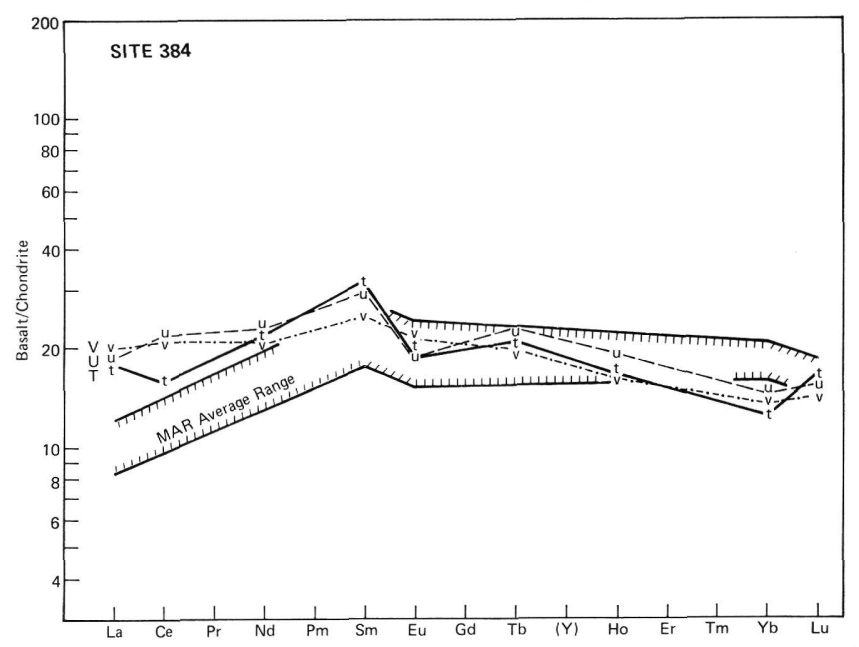

Figure 11. REE abundances in Site 384 basalts compared to a chondritic average. The range of average midoceanic ridge basalts is determined from data yielding average $(B B)$ in Tables $5 a$ and $b$. Letter designations for specific basalt analyses are from Table 4.

ment diagrams (Figures 4 through 7) suqgest the basalt sample AA is indeed LIL-enriched like oceanic island tholeiites. The less altered sample $\mathrm{Z}$, however, consistently plots as an ocean ridge tholeiite. $\mathrm{V}$ concentrations in both samples are relatively low with respect to Site 386 basalts. Low $\mathrm{Co}$ and $\mathrm{Zr}$ concentrations may reflect diagenetic effects (Bass et al., 1973). As suggested by alteration trends at the other two sites, only Sr shows significant upward enrichment.

\section{DISCUSSION}

\section{New England Seamounts}

The New England seamounts (Figure 14) extend some $1300 \mathrm{~km}$ from the continental slope south of 
TABLE 5A

Comparative Basalt Major Element Compositions

\begin{tabular}{|c|c|c|c|c|c|c|c|c|c|c|}
\hline & (BB) & (CC) & (DD) & (EE) & $(\mathrm{FF})$ & (GG) & $(\mathrm{HH})$ & (II) & $(\mathrm{JJ})$ & (KK) \\
\hline $\mathrm{SiO}_{2}$ & 49.3 & & 50.4 & 49.04 & & & 36.7 & 35.7 & 36.2 & 36.2 \\
\hline $\mathrm{Al}_{2} \mathrm{O}_{3}$ & 15.7 & & 16.7 & 18.10 & & & 16.5 & 16.3 & 18.0 & 19.1 \\
\hline $\mathrm{FeO}^{*}$ & 8.71 & & 9.2 & 8.77 & & & 10.7 & 12.4 & 12.8 & 10.9 \\
\hline $\mathrm{MgO}$ & 9.1 & & 7.3 & 3.68 & & & 5.2 & 4.1 & 2.4 & 2.3 \\
\hline $\mathrm{CaO}$ & 11.4 & & 12.3 & 10.72 & & & 10.3 & 7.1 & 4.1 & 3.0 \\
\hline $\mathrm{Na}_{2} \mathrm{O}$ & 2.7 & & 2.54 & 2.53 & & & 2.1 & 2.0 & 1.9 & 2.0 \\
\hline $\mathrm{K}_{2} \mathrm{O}$ & 0.34 & & 0.43 & 1.09 & & & 1.8 & 2.0 & 1.9 & 2.0 \\
\hline $\mathrm{TiO}_{2}$ & 1.4 & & 1.42 & 3.74 & & & 3.1 & 4.0 & 5.7 & 5.7 \\
\hline $\mathrm{MnO}$ & 0.16 & & 0.13 & 0.08 & & & 0.25 & 0.25 & 0.24 & 0.28 \\
\hline $\mathrm{P}_{2} \mathrm{O}_{5}$ & 0.16 & & n.d. & 0.08 & & & 1.6 & 1.9 & 2.7 & 2.2 \\
\hline $\mathrm{H}_{2} \mathrm{O}^{+}$ & $\begin{array}{l}0.74 \\
0.28\end{array}$ & & & 1.84 & & & \} 10.3 & 12.4 & \} 14.6 & $\{15.7$ \\
\hline $\begin{array}{l}\mathrm{H}_{2} \mathrm{O}^{-} \\
\mathrm{CO}_{2}\end{array}$ & $\begin{array}{l}0.28 \\
\text { n.d. }\end{array}$ & & n.d. & n.d. & & & n.d. & n.d. & 0.15 & n.d. \\
\hline Total & 99.99 & & 100.42 & 99.90 & & & 99.35 & 99.25 & 99.69 & 99.88 \\
\hline $\mathrm{FeO}^{*} / \mathrm{MgO}$ & 0.96 & & 1.26 & 2.38 & & & 2.06 & 3.02 & 5.33 & 4.74 \\
\hline
\end{tabular}

Note: $\mathrm{FeO}^{*}$ is total iron as $\mathrm{FeO}$; n.d. means not determined. See Table $5 \mathrm{~b}$ for sample designations.

TABLE 5B

Trace Element, $\mathrm{H}_{2} \mathrm{O}$, and $\mathrm{CO}_{2}$ Abundances and $\mathrm{Fe}_{2} \mathrm{O}_{3} / \mathrm{FeO}$ Ratios of Comparative Basalts

\begin{tabular}{|c|c|c|c|c|c|c|c|c|c|c|}
\hline & (BB) & (CC) & (DD) & (EE) & $(\mathrm{FF})$ & (GG) & $(\mathrm{HH})$ & (II) & $(\mathrm{JJ})$ & $(\mathrm{KK})$ \\
\hline \multicolumn{11}{|l|}{ Set I } \\
\hline $\mathrm{H}_{2} \mathrm{O}$ & 1.02 & 1.02 & 3.53 & 1.84 & & & 10.3 & 12.4 & 14.6 & 15.7 \\
\hline $\mathrm{CO}_{2}$ & n.d. & 0.94 & 1.63 & n.d. & & & n.d. & n.d. & 0.15 & n.d. \\
\hline $\mathrm{Fe}_{2} \mathrm{O}_{3} / \mathrm{FeO}$ & 0.27 & 0.94 & 1.82 & 0.35 & & & 2.5 & 2.8 & 6.0 & 5.6 \\
\hline $\mathrm{K}_{2} \mathrm{O}$ & 0.34 & 0.25 & 0.81 & 1.09 & & & 1.8 & 2.0 & 1.9 & 2.0 \\
\hline \multicolumn{11}{|l|}{ Set II } \\
\hline $\mathrm{Sc}$ & 39 & 42 & 35 & & & & & & & \\
\hline $\mathrm{V}$ & 244 & 250 & 225 & & & & & & & \\
\hline $\mathrm{Cr}$ & 539 & 310 & 320 & & & & & & & \\
\hline Co & 61 & 36 & 48 & & & & & & & \\
\hline $\mathrm{Ni}$ & 155 & 100 & 140 & & & & & & & \\
\hline $\mathrm{Cu}$ & 108 & 90 & 70 & & & & & & & \\
\hline $\mathrm{Zn}$ & n.d. & n.d. & n.d. & & & & & & & \\
\hline $\mathrm{Ga}$ & 16 & 18 & 19 & & & & & & & \\
\hline \multicolumn{11}{|l|}{ Set IIIA } \\
\hline $\mathrm{Sr}$ & 148 & 105 & 230 & & & & & & & \\
\hline $\mathrm{Ba}$ & 50 & 11 & 150 & & & & & & & \\
\hline $\mathrm{Y}$ & 32 & 35 & 26 & & & & & & & \\
\hline $\mathrm{Zr}$ & 83 & 85 & 95 & & & & & & & \\
\hline $\mathrm{Hf}$ & 2.10 & 2.46 & 3.10 & & & & & & & \\
\hline $\mathrm{Ta}$ & 0.13 & n.d. & 1.1 & & & & & & & \\
\hline \multicolumn{11}{|l|}{ Set IIIB } \\
\hline $\mathrm{La}$ & 3.13 & 2.7 & 11.3 & & 20.2 & 23.8 & & & & \\
\hline $\mathrm{Ce}$ & 9.16 & 9.0 & 27.6 & & 51.1 & 53.2 & & & & \\
\hline $\mathrm{Nd}$ & 8.14 & 7.8 & 13.1 & & 21.6 & 23.5 & & & & \\
\hline $\mathrm{Sm}$ & 2.27 & 2.86 & 3.0 & & 4.56 & 4.94 & & & & \\
\hline $\mathrm{Eu}$ & 0.86 & 1.15 & 1.11 & & 2.46 & 1.34 & & & & \\
\hline $\mathrm{Tb}$ & 0.59 & 0.73 & 0.53 & & 0.926 & 0.818 & & & & \\
\hline Ho & 0.79 & n.d. & 0.75 & & 1.00 & 0.854 & & & & \\
\hline $\mathrm{Yb}$ & 2.33 & 2.87 & 1.92 & & 2.56 & 1.98 & & & & \\
\hline $\mathrm{Lu}$ & 0.44 & 0.52 & 0.40 & & 0.442 & 0.360 & & & & \\
\hline $\mathrm{La} / \mathrm{Sm}$ & 1.38 & 0.944 & 3.77 & & 4.43 & 4.82 & & & & \\
\hline
\end{tabular}

Note: (BB) MAR average is average of 7 samples $30^{\circ} \mathrm{N}, 8$ samples $24-25^{\circ} \mathrm{N}, 19$ samples $9-11^{\circ} \mathrm{N}, 49$ samples $22^{\circ} \mathrm{N}$ (Frey et al., 1968; Kay et al., 1970; Frey et al., 1974); (CC) $2-11 \mathrm{~A}-7,1$ basalt (Frey et al., 1974); (DD) 2-10-20, 2 basalt (Frey et al., 1974); (EE) WMMS basalt from the Ossipee Mountains (Kingsley, 1931); (FF) WMMS basalt from the Belknap Mountains (Houghton, unpublished data); (GG) WMMS basalt from the Ossipee Mountains (Houghton, unpublished data); (HH) NES basalt, Gilliss Seamount, D-1-2 core (Taylor and Hekinian, 1971); (II) NES basalt, Gilliss Seamount, D-1-2 margin (Taylor and Hekinian, 1971); (JJ) NES basalt, Gilliss Seamount, D-1-A core (Taylor and Hekinian, 1971); (KK) NES basalt, Gilliss Seamount, D-1-A margin (Taylor and Hekinian, 1971). 


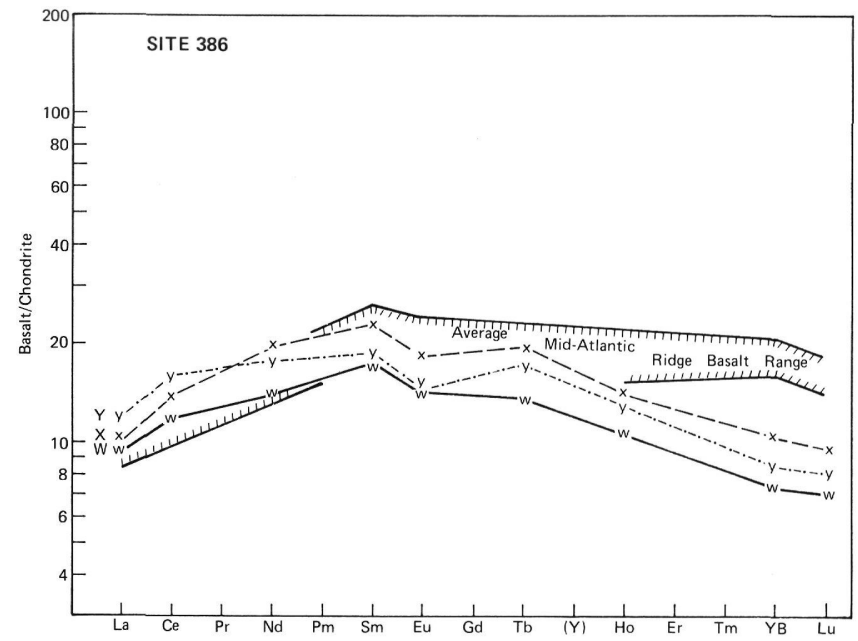

Figure 12. REE abundances in Site 386 basalts compared to a chondritic average. Letter designations for specific basalt analyses are from Table 4.

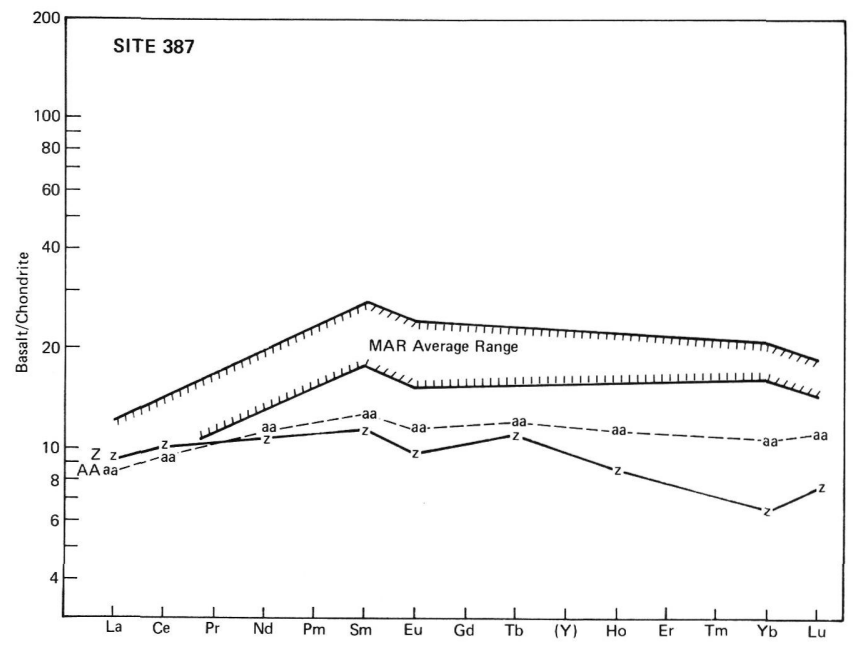

Figure 13. REE abundances in Site 387 basalts compared to a chondritic average. Letter designations for specific analyses are from Table 4.

Georges Bank to the outer Bermuda Rise in an arcuate pattern 70 to $200 \mathrm{~km}$ wide. Although this prominent linear seamount chain has been extensively bathymetrically surveyed (Tolstoy and Ewing, 1949; Tolstoy, 1951; Northrop and Frosch, 1954; Zeigler, 1955; Heezen et al., 1959; Northrop et al., 1962; Pratt and Thompson, 1962; Walczak, 1963; Walczak and Carter, 1964; Kontis and Young, 1965; Uchupi et al., 1970; Taylor and Hekinian, 1971; and numerous unpublished data), very little information has been available on the rocks of which it is built. Feden (1966) has described a badly weathered, ferro-manganese oxide encrusted, vesicular basalt from Caryn Seamount about $200 \mathrm{~km}$ south of the chain. Milliman and Emery (1968) recovered a few basaltic pebbles from scree on the summit of Bear Seamount with the submersible DSRV Alvin, and welded tuffs (identical to the volcaniclastic breccias cored during Leg 43) and amygdaloi- dal basalts were dredged from Bear and Mytilus seamounts by Zeigler (1955). Taylor and Hekinian (1971) attempted a systematic study of five extremely altered basalts (Table 5, analyses $\mathrm{HH}$ through KK) dredged from Gilliss Seamount, but were hindered by alteration problems.

The origin of the volcanic chain has been variously ascribed to (1) leaking of magma either progressively or simultaneously along a fracture zone or along the seaward propagation of a Paleozoic or older structural lineament in the Appalachians (Drake et al., 1968; Uchupi et al., 1970; Le Pichon and Fox, 1971); or (2) northwest motion of the North American plate over a nearly fixed mantle hot spot (Coney, 1971; Vogt et al., 1971; Morgan, 1973; Vogt, 1973). Geophysical methods have not allowed distinguishing between these two evolutionary histories and have provided equivocal evidence for both hypotheses. Detailed arguments for each origin are presented by Houghton et al., this volume.

Petrographic and geochemical studies of the Leg 43 basalts show that at least Nashville and Vogel seamounts are composed of highly alkaline basaltic lavas. Uncertainty about the extent of alterationinduced chemical changes in all Leg 43 basalts precludes interpreting trace element characteristics as functions of differentiation.

Even evaluation of magmatic type in type 5 basalt is questionable. Immobile element diagrams (Figures 4, 6 , and 7 , analysis $J$ ) suggest that the basalt has affinity with oceanic island tholeiites. Although enriched in $\mathrm{Co}$, the basalt is depleted in $\mathrm{Ni}$ in comparison with most tholeiites. Further, the basalt falls in the alkali basalt field on a $\mathrm{TiO}_{2}$ versus $\mathrm{Y}$ diagram (Figure 5). A mildly alkaline basalt could conceivably alter to the observed composition. Tholeiites are scarce on seamounts and may only characterize the larger layer islands (e.g., Hawaii, Iceland, Reunion, Galapagos, St. Paul, Amsterdam). Exceptions, such as Discovery Tablemount in the South Atlantic (Kempe and Schilling, 1974), are known but generally include only suggested hot spot traces.

The $\mathrm{La} / \mathrm{Sm}$ ratio of the possible tholeiite from Nashville (2.92) is higher than that of most LILelement enriched oceanic island tholeiites (Peterman and Hedge, 1971). All alkali basalts, however, possess similarly large ratios. This ratio has been employed by Schilling (1973a, b) and Kempe and Schilling (1974) as an indicator of mantle hot spot traces but is far from conclusive, especially for altered rocks. La tends to be enriched with respect to Sm during sea-floor weathering (Frey et al., 1974), thus generating similarly high ratios. As analogous LIL-element-enriched alkalic and tholeiitic basalts have been reported from fracture zones (Thompson and Melson, 1972; Schilling, 1975; White et al., 1976), proposed hot spot locations (Schilling, 1973a, b; Yeats et al., 1973; Sun et al., 1975 and other tectonic regimes, distinction between these two modes of origin for the New England seamount lavas is not possible with present chemical data. Studies continuing on the Leg 43 basalts and volcanic rocks 


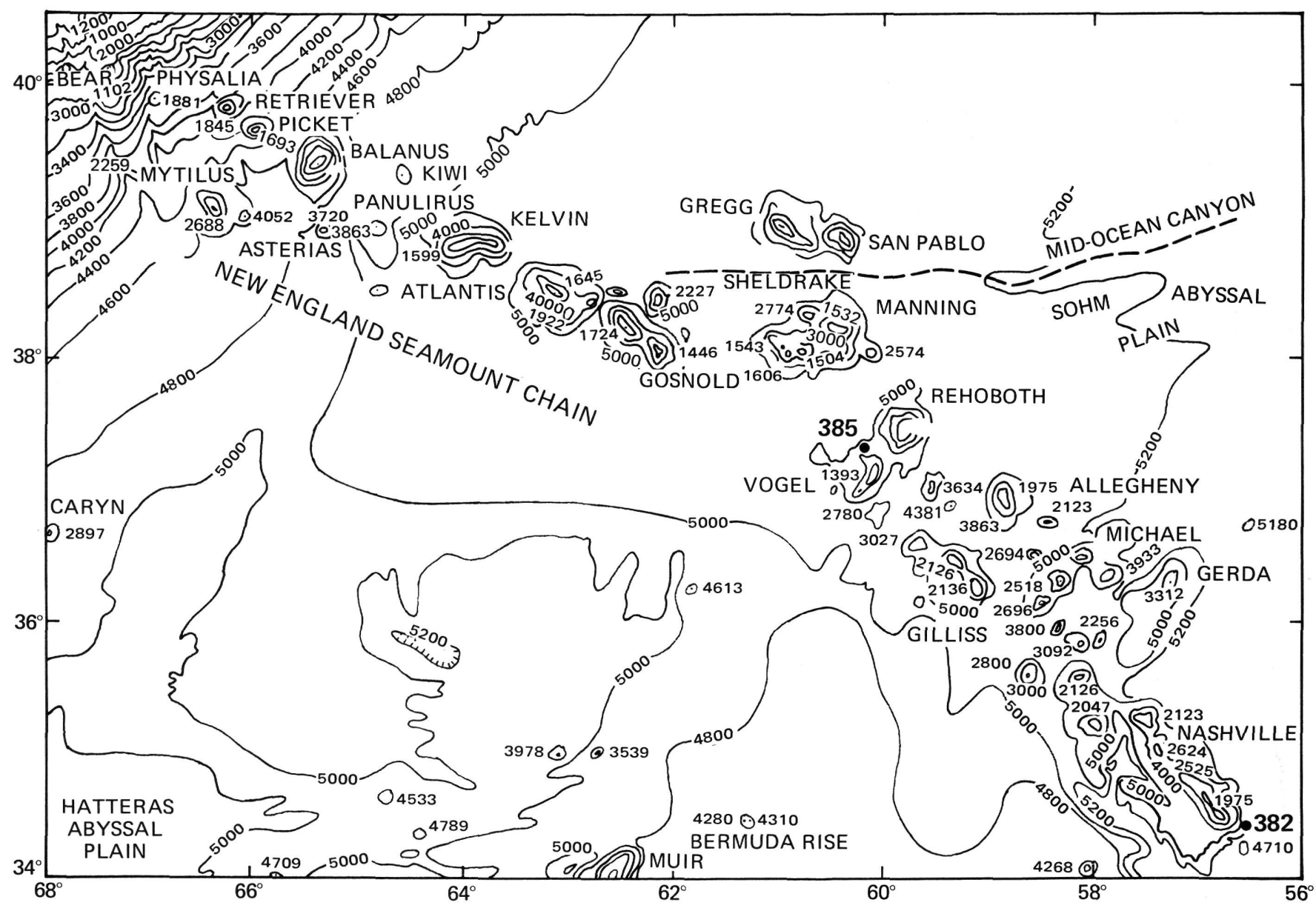

Figure 14. Bathymetric map of the New England, seamounts showing DSDP Sites 382 and 385.

recovered from the seamounts by dredging and submersible dives during R. V. Atlantis II Cruise 85 and R. V. Knorr Cruise 42 by this author are designed to help elucidate this relationship.

Because a broad belt of recent seismicity lies along an extension of the New England seamount chain into New England and southeastern Canada and follows the trend of the White Mountain Magma Series, some authors have suggested that these ring-dike complexes represent the continental extension of the seamount chain (Griscom and Bromery, 1968; Morgan, 1971; Rhodes, 1971; Ballard and Uchupi, 1972). The scarcity of data on the mafic rocks of the White Mountain Magma Series (Table 5, analyses EE through GG) makes comparison difficult. REE patterns of flow basalt from the Ossippee and Belknap Mountains (Figure 15) are similar to New England seamount basalt types 2 and 3, but they have been affected by dissimilar weathering processes and are insufficient to attempt quantitative fractionation modeling. Immobile element relationships (Figures 4 through 7) are also complementary.

A Miocene sill drilled on the flank of Vogel Seamount chemically resembles another sill of like age drilled at Site 10, approximately midway between Nashville Seamount and Corner Rise. The possible age

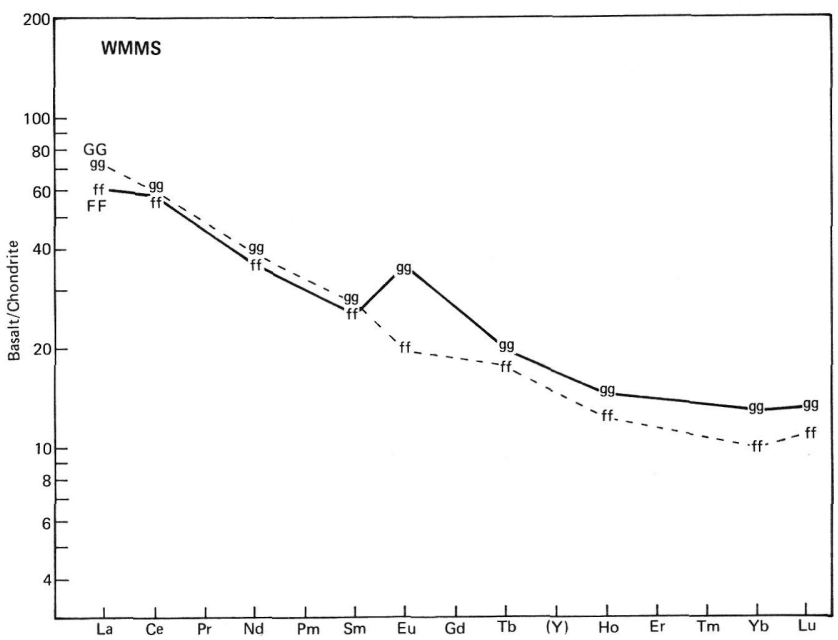

Figure 15. REE abundances in basalts of the White Mountain Magma Series from the Ossipee (EE) and Belknap (FF) Mountains compared to a chondritic average. Data are from Table $5 b$.

equivalence of these two features is discussed by Houghton et al. (this volume). The chemical resemblance of the two basalts strongly argues for a similar, if not common, source and history. Although no evi- 
dence for a post-orogenic resurgence was observed during seven dives of the DSRV Alvin (Heirtzler et al., 1974, 1977; Houghton and Ballard, in preparation), renewed volcanic activity along a structural conduit connecting the New England seamounts and Corner Rise is possible. In support of this suggestion, a single pillow basalt recovered from the Corner Rise during $\mathrm{R}$. V. Trident Cruise 71 is petrographically similar to New England seamount type 1 .

\section{$J$-Anomaly Ridge}

In the western North Atlantic, the " $J$ " magnetic anomaly is associated with a complex basement ridge, part of which emerges above the sea floor at Site 384 . Drilling was planned to date oceanic basement and to test the origin of this magnetic feature. The former objective was satisfactorily achieved (see Houghton et al., this volume), but alteration effects and limited basement recovery prevent definitive magnetic studies.

This high amplitude anomaly must represent an unusual event at the ridge crest, because it is found to occur on both sides of the Atlantic Ocean (Pitman and Talwani, 1972; Laughton and Whitmarsh, 1974). The end of the Keathley magnetic sequence is not characterized by anomalous amplitides in the Pacific, so a geomagnetic explanation is ruled out. Three possibilities remain. The $J$-anomaly could reflect (1) a thickened pillow lava layer of otherwise normal composition and magnetization; (2) a large anomalous mass of gabbro, serpentinite, or both underlying a normal pillow sequence; or (3) anomalous composition and/or magnetization of the pillow lava layer. Basalts with 2 to 3 times normal $\mathrm{FeO} \delta$ and $\mathrm{TiO}_{2}$ contents and associated high magnetism have been reported near proposed hot spots (e.g., Juan de Fuca and Galapagos ridges; Vogt and Johnson, 1973).

Less than 2 meters of basalt recovery at Site 384 provides insufficient sample to properly investigate any of the above hypotheses. Further, combined lowtemperature and hydrothermal alteration cloud chemical interpretations. Although slightly enriched in certain LIL elements, Site 384 basalts appear to be typical of oceanic ridge lavas. No unusual $\mathrm{Fe}$, $\mathrm{Ti}$, or magnetite concentrations were observed. REE patterns (Figure 11), and other trace element concentrations support this conclusion and show no evidence of extensive fractionation to generate an underlying cumulate. Seismic refraction studies are required to adequately test the first two hypotheses. However, the high elevation of the ridge might favor an isostatically uncompensated underlying ultramafic body (Dick, 1975).

\section{Western North Atlantic Sea Floor}

Basalt recovered at Site 386 on the Bermuda Rise is typical of oceanic ridge tholeiites in the Atlantic. As basalt recovered at Site 387 is of questionable origin, changes in the petrology of crust generated at the Mesozoic ridge cannot be evaluated. Petrographically, however, Site 386 basalt displays the same groundmass texture of randomly oriented plagioclase microlites with intergranular pyroxene described for basalt from Site 100 (Bryan, 1972). The more plumose intergrowths of Site 105 (Bryan, 1972) appear more typical of the complex groundmass encountered at Site 387 . Chemically, both Site 386 and Site 387 basalts are depleted in $\mathrm{Sc}$ and $\mathrm{V}$ and enriched in $\mathrm{Sr}$ and $\mathrm{Ba}$ with respect to Site 11 basalt (Table 5, analysis CC). These differences, however, are probably due to alteration and do not reflect the primary composition of the magma. The basalt at Site 386 has a more fractionated and more sharply depleted REE pattern (Figure 12) than that of Site 11. The latter is similar in its REE patterns to Site 387 basalt. This relationship suggests that the basalt at Site 386 is more evolved than previously analyzed western Atlantic basalts.

Identification of Site 387 basalt as a sill is largely dependent on petrographic and structural considerations. Chemically, sample AA is an LIL-element enriched tholeiite, consistent with emplacement at a distance from the ridge. If the basalt is a sill, age considerations (Houghton et al., this volume) suggest that intrusion took place shortly after basement was formed. Chemical analysis of sample $Z$ from this site, however, suggests it is a normal ocean ridge tholeiite. The depleted REE contents of both basalts are consistent with this origin. If the basalt represents true basement at this site, it is likely that at least two flows were sampled. It is unlikely that the LIL-element enrichments of sample AA could result from alteration. Comparison with the basaltic section recovered at Site 335 is consistent with either origin.

\section{ACKNOWLEDGMENTS}

Thanks are extended to A. Parks and M. Loiselle for help in the laboratory procedures. The nuclear reactor irradiations were made at the Massachusetts Institute of Technology nuclear reactor. We gratefully acknowledge the support and critical review of W. B. Bryan, F. A. Frey, S. Hart, and G. Thompson during this work.

This is Contribution No. 3851 of Woods Hole Oceanographic Institution.

\section{REFERENCES}

Aoki, K., 1963. The kaersutites and oxykaersutites from alkalic rocks of Japan and surrounding areas: J. Petrol., .v. 4, p. 198.

Baker, I., 1969. Petrology of volcanic rocks of Saint Helena Island, South Atlantic: Geol. Soc. Am. Bull., v. 80, p. 1283-1310.

Baker, P. E., Buckley, F., and Holland, J. G., 1974. Petrology and geochemistry of Easter Island: Contrib. Mineral. Petrol., v. 4, p. 85-100.

Ballard, R. D. and Uchupi, E., 1972. Carboniferous and Triassic rifting: A preliminary outline of the tectonic history of the Gulf of Maine: Geol. Soc. Am. Bull., v. 83, p. 2285-2302.

Bass, M. N., Moberly, R., Rhodes, J. M., Shih, C.-Y., and Church, S. E., 1973. Volcanic rocks cored in the central Pacific, Leg 17, Deep Sea Drilling Project. In Winterer, E. L., Ewing, J. I., et al., Initial Reports of the Deep Sea Drilling Project, v. 17: Washington (U. S. Government Printing Office) p. 429-446. 
Bryan, W. B., 1972. Textural and mineralogical relations of basalts from Sites 100 and 105. In Hollister, C. O., Ewing, J. I., et al., Initial Reports of the Deep Sea Drilling Project v. 11: Washington (U. S. Government Printing Office), p. 873-876.

Cann, J. R., 1970. Rb, Sr, Y, Zr, Nb in some ocean floor basaltic rocks: E.P.S.L., v. 10, p. 7-11.

1971. Major element variations in ocean-floor basalts: Phil. Trans. Roy. Soc. London, Ser. A., v. 268, p. 495-505.

Coney, P. J., 1971. Cordilleran tectonic transitions and motions of the North American plate: Nature, v. 223, p. 462-465.

Dick, H. J. B., 1975. The origin and emplacement of the Josephine peridotite, southwestern Oregon: Ph.D. Thesis, Yale University.

Drake, C. L., Ewing, J. I., and Stockard, H., 1968. The continental margin of the eastern United States: Canadian J. Earth Sci., v. 5, p. 993-1010.

Engel, A. E. J., Engel, C. G., and Havens, R. G., 1965. Chemical characteristics of oceanic basalts and the upper mantle: Geol. Soc. Am. Bull., v. 76, p. 719-734.

Feden, R. H., 1966. Volcanic rock from Caryn Seamount: $J$. Geophys. Res., v. 71, p. 1761-1763.

Flanagan, F. J., 1973. 1972 values for international geochemical reference samples: Geochim. Cosmochim. Acta, v. 37, p. $1189-1200$.

Flower, M. F. J., 1973. Trace element distribution in lavas from Anjouan and Grande Camore, western Indian Ocean: Chem. Geol., v. 12, p. 81-98.

Floyd, P. A. and Winchester, J. A., 1975. Magma type and tectonic setting discrimination using immobile elements: E.P.S.L., v. 27, p. 211-218.

Frey, F. A., Haskin, M. A., Poetz, J. and Haskin, L. A., 1968. Rare earth abundances in some basic rocks: J. Geophys. Res., v. 73, p. 6085-6098.

Frey, F. A., Bryan, W. B., and Thompson, G., 1974. Atlantic Ocean floor: Geochemistry and petrology of basalts from Legs 2 and 3 of the Deep Sea Drilling Project: J. Geophys. Res., v. 79, p. 5507-5527.

Gass, I. G., Mallick, D. I. J., and Cox, K. G., 1973. Volcanic islands of the Red Sea: J. Geol. Soc. London, v. 129, p. 275-310.

Gordon, G. E., Randle, K., Goles, G., Corliss, J., Beeson, M., and Oxley, S., 1968. Instrumental activation analysis of standard rocks with high resolution gamma ray detectors: Geochim. Cosmochim. Acta, v. 32, p. 369-396.

Griscom, E. and Bromery, R. W., 1968. Geologic interpretation of aeromagnetic data for New England. In E-an Zen et al., (Eds.), Studies in Appalachian Geology: Northern and Maritime: New York (Interscience) p. 425-430.

Gunn, B. M. and Watkins, N. D., 1976. Geochemistry of the Cape Verde Islands and Fernando de Noronha: Geol. Soc. Am. Bull., v. 87, p. 1089-1100.

Hart, S. R., 1969. K, Rb, Cs contents and K/Rb, K/Cs ratios of fresh and altered submarine basalts: E.P.S.L., v. 6, p. 295-303.

Heezen, B. C., Tharp, M., and Ewing, M., 1959. The floors of the oceans-I. The North Atlantic: Geol. Soc. Am. Spec. Paper, v. 65, p. 1-122.

Heirtzler, J. R., Ballard, R. D., Houghton, R. L., and Taylor, P. T., 1974. An investigation of the New England Seamounts by submersible, EOS., v. 56 p. 1138.

Heirtzler, J. R., Taylor, P. T., Ballard, R. D., and Houghton, R. L., 1977. A visit to the New England Seamounts: Am. Sci., v. 65, p. 466-472.
Houghton, R. L. and Ballard, R. D., in preparation. Tectonic and petrologic observations of the New England Seamounts.

Kay, R., Hubbard, N. J., and Gast, P. W., 1970. Chemical characteristics and origin of oceanic ridge volcanic rocks: J. Geophys. Res., v. 75, p. 1585-1613.

Kempe, D. R. C. and Schilling, J.-G., 1974. Discovery Tablemount basalt: Petrology and geochemistry: Contrib. Mineral. Petrol., v. 44, p. 101-115.

Kingsley, L., 1931. Cauldron subsidence of the Ossipee Mountains, New Hampshire: Am. J. Sci., v. 22, p. 139168.

Kontis, A. L. and Young, G. A., 1965. A study of aeromagnetic data-New England Seamount area: Tech. Rept. U.S. Nav. Oceanogr. Off. TR-166, p. 1-18.

Laughton, A. S. and Whitmarsh, R. B., 1974. The AzoresGibraltar plate boundary. In Kristjansson (Ed.), Geodynamics of Iceland and the North Atlantic Area, DordrechtHolland (D. Reidel Pub. Co.), p. 63-81.

Le Maitre, R. W., 1962. Petrology of volcanic rocks, Gough Island, South Atlantic: Geol. Soc. Am. Bull., v. 73, p. 1309-1340.

Le Pichon, X. and Fox, P. J., 1971. Marginal offsets, fracture zones and the early opening of the North Atlantic: $J$. Geophys. Res., v. 76, p. 6294-6308.

Maxwell, J. A., 1968. Rock and mineral Analysis: New York (Interscience).

Melson, W. G. and Thompson, G., 1971. Petrology of a transform fault zone and adjacent ridge segments: Phil. Trans. Roy. Soc. London, v. 268, p. 423-441.

Melson, W. G., Thompson, G., and van Andel, Tj. H., 1968. Volcanism and metamorphism in the Mid-Atlantic Ridge, $22^{\circ} \mathrm{N}$ latitude: J. Geophys. Res., v. 73, p. 5925-5941.

Milliman, J. D. and Emery, K. O., 1968. Sea levels during the past 35,000 years: Science, v. 162, p. 1121-1123.

Morgan, W. J., 1971. Convection plumes in the lower mantle: Nature, v. 230, p. 42-43. , 1973. Plate motions and deep mantle convection, In Shagam (Ed.), Studies in earth and space science, Hess Volume: Geol. Soc. Am. Mem., v. 132, p. 7-22.

Muir, I. D. and Tilley, C. E., 1964. Basalts from the northern part of the rift zone of the Mid-Atlantic Ridge: J. Petrol., v. 5 , p. $409-434$.

Nockolds, S. R. and Allen, R., 1954. Geochemistry of some igneous rock series, II: Geochim. Cosmochim. Acta, v. 5, p. 245-285.

Northrop, J. and Frosch, R. A., 1954. Seamounts in the North Atlantic basin: Deep-Sea Res., v. 1, p. 252-257.

Northrop, J. R., Frosch, A., and Frassetto, R., 1962. Bermuda-New England Seamount arc: Geol. Soc. Am. Bull., v. 73 , p. $587-594$.

Parsons, W. H., 1968. Subaqueous volcanic breccias in New Zealand: Geol. Soc. Am. Spec. Pap., p.

Parsons, W. H. 1969. Criteria for the recognition of volcanic breccias: Review. In Larsen, Prinz, and Manson (Eds.), Igneous and Metamorphic Petrology, Geol. Soc. Am. Mem., v. 115 , p. $263-304$.

Pearce, J. A. and Cann, J. R., 1973. Tectonic setting of basic volcanic rocks determined using trace element analyses: E.P.S.L., v. 19, p. 290-300.

Peterman, Z. E. and Hedge, C. E., 1971. Related strontium isotopic and chemical variations in oceanic basalts: Geol. Soc. Am. Bull., v. 82, p. 493-500.

Pitman, W. C., III, and Talwani, M., 1972. Sea-floor spreading in the North Atlantic: Geol. Soc. Am. Bull., v. 83, p. 619-646. 
Pratt, R. M. and Thompson, S. L., 1962. Report of Atlantis Cruises No. 280-281: W.H.O.I. Ref. No. 62-40, p. 1-20.

Reynolds, R., 1963. Matrix corrections in trace element analysis by $\mathrm{x}$-ray fluorescence: Estimation of the mass absorption coefficient by Compton scattering: Am. Mineralogist, v. 48, p. 1133-1143.

1967. Estimation of mass absorption coefficients by Compton scattering: Improvements and extensions of the method: Am. Mineralogist, v. 52, p. 1493-1502.

Rhodes, R. C., 1971. Structural geometry of subvolcanic ring complexes as related to pre-Cenozoic motions of continental plates: Techtonophysics, v. 12, p. 111-117.

Schilling, J. G., 1973a. Iceland mantle plume: Geochemical study of Reykjanes Ridge: Nature, v. 242, p. 565-571. 1973b. Iceland mantle plume-Reykjanes Ridge system II. Mixing model formulation based on geochemical gradients along the ridge axis, and its implications on crustal structure: J. Geophys. Res., v. 79, p.

1975. Rare-earth variations across 'normal segments' of the Reykjanes Ridge $60^{\circ}-53^{\circ} \mathrm{N}$, Mid-Atlantic Ridge $29^{\circ} \mathrm{S}$, and East Pacific Rise $2^{\circ}-19^{\circ} \mathrm{S}$ and evidence on the composition of the underlying low-velocity layer: $J$. Geophys. Res., v. 80, p. 1459-1473.

Sun, S. S., Tatsumoto, M., and Schilling, J. G., 1975. Mantle plume mixing along the Reykjanes Ridge axis: Lead isotopic evidence: Science, v. 190, p. 143-147.

Taylor, P. T. and Hekinian, R., 1971. Geology of a newly discovered seamount in the New England Seamount chain: E.P.S.L., v. 11, p. 73-82.

Thompson, G., 1973. A geochemical study of the lowtemperature interaction of sea-water and oceanic igneous rocks: $E O S$, v. 54, p. 1015-1018.

Thompson, G. and Melson, W. G., 1972. The petrology of oceanic crust across fracture zones in the Atlantic Ocean: Evidence of a new kind of sea-floor spreading: J. Geol., v. 80 , p. $526-538$.
Tolstoy, I., 1951. Submarine topography in the North Atlantic: Geol. Soc. Am. Bull., v. 62, p. 441-450.

Tolstoy, I. and Ewing, M., 1949. Atlantic hydrography and the Mid-Atlantic Ridge: Geol. Soc. Am. Bull., v. 60, p. 1527-1540.

Uchupi, E., Phillips, J. D., and Prada, K. E., 1970. Origin and structure of the New England Seamount chain: Deep-Sea Res., v. 17, p. 483-494.

Vogt, P., 1973. Early events in the opening of the North Atlantic. In Tarling and Runcorn (Eds.), Implications of Continental Drift to the earth sciences: New York (Academic Press), p. 693-712.

Vogt, P. R. and Johnson, G. L., 1973. Magnetic telechemistry of oceanic crust?: Nature, v. 245, p. 373-375.

Vogt, P. R., Anderson, C. N., and Bracey, D. R., 1971. Mesozoic magnetic anomalies, sea-floor spreading, and geomagnetic reversals in the south western North Atlantic: J. Geophys. Res., v. 76, p. 4796-4823.

Walczak, J. E., 1963. A marine magnetic survey of the New England Seamount chain: Tech. Rept. U.S. Nav. Oceanogr. Off. TR-159, p. 1-37.

Walczak, J. E. and Carter, T., 1964. A bathymetric and geomagnetic survey of the New England Seamount chain: Intl. Hydro. Rev., v. 61, p. 59-67.

White, W. M., Schilling, J.-G., and Hart, S. R., 1976. Evidence for the Azores mantle plume from strontium isotopes geochemistry of the central North Atlantic, Nature, v. 263, p. 659-663.

Yeats, R. S., Forbes, W. C., Heath, G. R., and Scheidegger, K. F., 1973. Petrology and geochemistry of the DSDP Leg 16 basalts, eastern equatorial Pacific. In van Andel, Tj. H., Heath, G. R., et al., Initial Reports of the Deep Sea Drilling Project, v. 16: Washington (U. S. Government Printing Office), p. 617-640.

Zeigler, J. M., 1955. Seamounts near the eastern coast of North America: W.H.O.I. Ref. No. 55-17, p. 1-16. 